\title{
Large clean mesocosms and simulated dust deposition: a new methodology to investigate responses of marine oligotrophic ecosystems to atmospheric inputs
}

\author{
C. Guieu ${ }^{1,2}$, F. Dulac ${ }^{3,4}$, K. Desboeufs ${ }^{4}$, T. Wagener $^{1,{ }^{*}}$, E. Pulido-Villena ${ }^{1,2}$, J.-M. Grisoni $^{5}$, F. Louis ${ }^{1,2}$, C. Ridame $^{6}$, \\ S. Blain ${ }^{7,8}$, C. Brunet ${ }^{9}$, E. Bon Nguyen ${ }^{4}$, S. Tran ${ }^{4}$, M. Labiadh ${ }^{10}$, and J.-M. Dominici ${ }^{11}$ \\ ${ }^{1}$ Laboratoire d'Océanographie de Villefranche/Mer, CNRS-INSU, UMR7093, Observatoire Océanologique, \\ 06230, Villefranche-sur-Mer, France \\ ${ }^{2}$ Université Pierre et Marie Curie-Paris 6, UMR 7093, LOV, Observatoire Océanologique, \\ 06230, Villefranche-sur-Mer, France \\ ${ }^{3}$ Laboratoire des Sciences du Climat et de l'Environnement, CEA-CNRS-UVSQ, Gif-Sur-Yvette, France \\ ${ }^{4}$ Laboratoire Interuniversitaire des Systèmes Atmosphériques (LISA), Université Paris VII, Créteil, France \\ ${ }^{5}$ Observatoire Océanologique de Villefranche/Mer, CNRS-UPMC, Villefranche-sur-Mer, France \\ ${ }^{6}$ Laboratoire d'Océanographie et du Climat: Expérimentations et Approches Numériques (LOCEAN), CNRS-Université \\ Paris VI, Campus Jussieu, Paris, France \\ ${ }^{7}$ CNRS, UMR 7621, LOMIC, Observatoire Océanologique, 66651, Banyuls/mer, France \\ ${ }^{8}$ Université Pierre et Marie Curie-Paris 6, UMR 7621, LOMIC, Observatoire Océanologique, 66651, Banyuls/mer, France \\ ${ }^{9}$ Laboratory of Ecology and Evolution of Plankton, Stazione Zoologica Anton Dohrn, Napoli, Italy \\ ${ }^{10}$ Institut des Régions Arides (IRA), Medenine, Tunisia \\ ${ }^{11}$ Parc Naturel Régional Corse, Galéria, France \\ * now at: Université de la Méditerranée, Centre Océanologique, Marseille, France
}

Received: 10 March 2010 - Published in Biogeosciences Discuss.: 12 April 2010

Revised: 3 September 2010 - Accepted: 7 September 2010 - Published: 20 September 2010

\begin{abstract}
Intense Saharan dust deposition occurs over large oligotrophic areas in the Mediterranean Sea and in the Tropical Atlantic, and its impact on the biogeochemical functioning of such oligotrophic ecosystems needs to be understood. However, due to the logistical difficulties of investigating in situ natural dust events, and due to the inherent limitations of microcosm laboratory experiments, new experimental approaches need to be developed. In this paper, we present a new experimental setup based on large, clean mesocoms deployed in the frame of the DUNE (a DUst experiment in a low-Nutrient, low-chlorophyll Ecosystem) project. We demonstrate that these tools are highly relevant and provide a powerful new strategy to in situ studies of the response of an oligotrophic ecosystem to chemical forcing by atmospheric deposition of African dust. First, we describe how to cope with the large amount of dust aerosol needed to conduct the seeding experiments by producing an analogue from soil collected in a source area and by performing subsequent
\end{abstract}

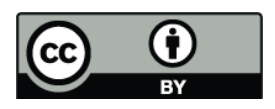

Correspondence to: C. Guieu (guieu@obs-vlfr.fr) appropriate physico-chemical treatments in the laboratory, including an eventual processing by simulated cloud water. The comparison of the physico-chemical characteristics of produced dust analogues with the literature confirms that our experimental simulations are representative of dust, aging during atmospheric transport, and subsequent deposition to the Mediterranean. Second, we demonstrate the feasibility in coastal areas to installing, in situ, a series of large $\left(6 \times 52 \mathrm{~m}^{3}\right)$ mesocosms without perturbing the local ecosystem. The setup, containing no metallic parts and with the least possible induced perturbation during the sampling sequence, provides an approach for working with the required conditions for biogeochemical studies in oligotrophic environments, where nutrient and micronutrients are at nano- or subnano-molar levels. Two, distinct "seeding experiments" were conducted by deploying three mesocosms serving as controls $($ CONTROLS-Meso $=$ no addition $)$ and three mesocosms seeded with the same amount of Saharan dust (DUSTMeso $=10 \mathrm{~g} \mathrm{~m}^{-2}$ of sprayed dust). A large panel of biogeochemical parameters was measured at $0.1 \mathrm{~m}$, at $5 \mathrm{~m}$ and $10 \mathrm{~m}$ in all of the mesocosms and at a selected site outside the

Published by Copernicus Publications on behalf of the European Geosciences Union. 
mesocosms before seeding and at regular intervals afterward. Statistical analyses of the results show that data from three mesocosms that received the same treatment are highly reproducible (variability $<30 \%$ ) and that there is no significant difference between data obtained from CONTROLS-Meso and data obtained outside the mesocosms.

This paper demonstrates that the methodology developed in the DUNE project is suitable to quantifying and parameterizing the impact of atmospheric chemical forcing in a lownutrient, low-chlorophyll (LNLC) ecosystem. Such large mesocosms can be considered as 1-D ecosystems so that the parameterization obtained from these experiments can be integrated into ecosystem models.

\section{Introduction}

The biogeochemical impacts of atmospheric, dust-derived $\mathrm{Fe}$ and other nutrients on oligotrophic LNLC environments are still poorly understood. This issue has received little attention in comparison to the large number of investigations of the impact of iron supply on the productivity of high nutrientlow chlorophyll (HNLC) oceanic regions using bioassay experiments (Martin et al., 1994), mesoscale artificial iron fertilization experiments (see synthesis by de Baar et al., 2005; Boyd et al., 2007) and natural fertilization studies (Pollard et al., 2007; Blain et al., 2008). However the LNLC oceanic regions represent $60 \%$ of the global ocean (Longhurst et al., 1995) and over $50 \%$ of the global oceanic carbon export (Emerson et al., 1997).

The biogeochemical effects of dust in LNLC waters have only been explored very recently through microcosm experiments, where different combinations of nutrients and dust were added to a natural assemblage of plankton. In two LNLC environments that receive episodic and strong dust deposition the tropical Atlantic (Mills et al., 2004), and the Mediterranean Sea (see for example Herut et al., 2005; Pulido-Villena et al., 2008), dust additions in microcosms showed moderate, but significant, responses in both heterotrophic and autotrophic organisms. Although such microcosm approaches can yield valuable information on specific forcing upon a given natural assemblage, the results are difficult to extrapolate to large marine areas or to time scales that exceed the duration of the experiment. Moreover, relying upon a fixed and homogeneously-distributed concentration of particles can alter the dust dissolution kinetics and does not account for particle migration through the water column. This precludes any estimation of $\mathrm{C}$ export induced by atmospheric deposition. Consequently, the question of the in situ biological response of LNLC regions and, particularly, of the Mediterranean Sea to atmospheric inputs has not yet been fully answered.

To address this gap in methodology, we have developed a novel approach to studying the effects of atmospheric inputs on a typical LNLC ecosystem. The strategy is based on the addition of aerosols to large and trace-metal-free mesocosms that are more representative of the processes taking place in situ as compared to a typical microcosm approach. The objective was to test, on a relevant number of biogeochemical parameters, the impact of a desert dust event on the natural planktonic community of a large water body in perfectly-controlled conditions. This was developed in the frame of the DUNE project (a DUst experiment in a low Nutrient, low chlorophyll Ecosystem; http://www.obs-vlfr. fr/LOV/DUNE). The aim of this paper is to describe our original methodology and to demonstrate that it is highly relevant to meeting our objectives. The detailed results and discussions of the biogeochemical and ecosystem responses obtained are considered in other papers (see for ex. PulidoVillena et al., 2010; Wagener et al., 2010; Lagdhass et al., 2010; Ridame et al., 2009, 2010; Desboeufs et al., 2010).

This paper gives a detailed description of the methodology developed and applied during the first DUNE experiment (DUNE-1) in June 2008 during which two seeding experiments were conducted upon six large $\left(52 \mathrm{~m}^{3}\right)$ mesocosms. After a brief overview of the chosen LNLC site in the Mediterranean Sea, we will discuss the different aspects related to the Saharan particles that have been used for seeding the mesocosms. We then review the setup that was designed for the experimental mesocosm platform and the description of the sequence of the experiment. Finally, the last section provides a comparison of selected results versus the entire data set obtained, demonstrating the effectiveness of the methodology to providing robust quantification and parameterization regarding the impact of atmospheric chemical forcing on a LNLC ecosystem.

\section{The Scandola: an oligotrophic coastal "pristine" area}

The experiment was conducted in a remote, coastal, lownutrient, low-chlorophyll (LNLC) area of the Mediterranean Sea: the Natural Preservation Area of Scandola (Fig. 1), a marine and terrestrial zone protected from human activities since its creation in 1975 (http://www.parc-naturel-corse. com/patrimoine/scandola.html). A preliminary field study took place in May 2006 during which a careful inspection of the best location to conduct the seeding experiment was performed. The selected site (Elbo Bay, see Fig. 1) has a seafloor at $\sim 30 \mathrm{~m}$ depth. There is no terrestrial access, and several restrictions are imposed upon boat activities (e.g. no mooring allowed during night-time). The closest town is Galéria, a small village located at 5.88 miles $/ 11 \mathrm{~km}$, and there is no industrial activity in the region. There are no nearby rivers, and the site can only be influenced by direct runoff from the land. The site has been a choice for numerous studies on the influence of global change on natural ecosystems (see for ex. the project MedChange: http://piccard.esil.univmed.fr/ medchange/spip/spip.php?rubrique47). The dominant winds 

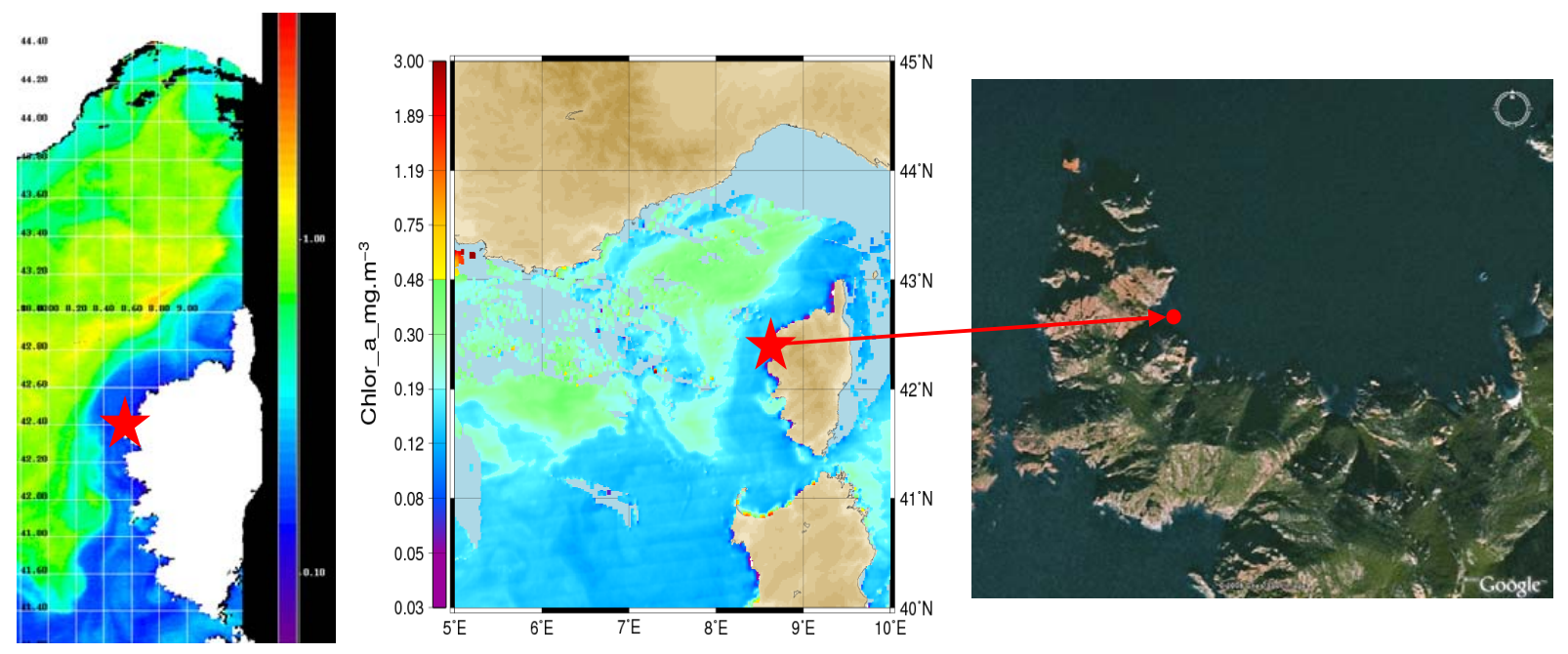

Fig. 1. MODIS satellite image showing the chlorophyll- $a$ distribution in the Ligurian Sea during the spring bloom (left image, 1 May 2008) and during the DUNE-1 experiment (central image, 16 June 2008); the DUNE mesocosm site in Scandola reserve on the coast of Corsica is marked in red: the site is characterized by "blue" waters typical of oligotrophic systems (source: MODIS, Nasa, E. Bosc, personal communication, 2008). The area chosen is a very "blue" area because of the uplift of the Ligurian Current along the Corsican coast that isolates the coastal area from more productive waters of the center of the Ligurian Sea: during both experiments, the waters were typical of oligotrophic conditions. The GoogleEarth ${ }^{\circledR}$ satellite image on the right shows the local configuration of the bay, protected from dominant westerly winds and swell by a peninsula.

in the area are SW; the dominant currents in the Elbo Bay allow the waters to move fast to the north (Romano et al., 2006 and personal communication, 2007). Apart from its remoteness, the site was selected because this part of the Mediterranean is representative of very clear ("blue") waters (Fig. 1).

\section{Producing the necessary amount of representative Saharan dust}

The mean, annual dust deposition flux in Corsica during the period 1984-1994 was $12.5 \mathrm{~g} \mathrm{~m}^{-2}$ (Loÿe-Pilot and Martin, 1996). In Corsica, several events per year yield a deposition flux larger than $1 \mathrm{~g} \mathrm{~m}^{-2}$, and more recently event fluxes of $\sim 22 \mathrm{~g} \mathrm{~m}^{-2}$ have been recorded: $21.9 \mathrm{~g} \mathrm{~m}^{-2}$ in November 2001 (Guieu et al., 2010), $22.2 \mathrm{~g} \mathrm{~m}^{-2}$ in February 2004 (Bonnet and Guieu, 2006; Ternon et al., 2010.). In our study we chose to mimic a high, but still realistic, Saharan dust deposition event of $10 \mathrm{~g} \mathrm{~m}^{-2}$. The surface area of each mesocosm was $4.15 \mathrm{~m}^{2}$ (see Sect. 4). The amount of dust per mesocosm used was $41.5 \mathrm{~g}$, which resulted in a total of $\sim 125 \mathrm{~g}$ of dust for the three replicates. Such a large amount of particles could not be collected from airborne dust in the vicinity of the experimental area and could hardly be collected in any source region. Thus, our strategy consisted of producing dust from the soil of an appropriate source area.

\subsection{Collection and production of the fine particles}

The frequency of Saharan dust events over the western Mediterranean basin increases between March and October, with its maximum intensity occurring during the dry season (June to August) (Bergametti et al., 1989; Moulin et al., 1998). The northeastern Sahara (eastern Algeria, southern Tunisia and western Libya) appears to be the major source of dust collected in Corsica during springtime (Bergametti et al., 1989; Guieu et al., 2002). In fact, seven out of eight of the dust events recorded in Corsica in March, April or May in 1985 and 1986 originated from this region (Fig. 2). Southern Tunisia was thus chosen as the source region to collect soil to produce the dust needed for seeding. For our superficial soil sampling zone, we selected the main dried affluent of Oued El Hallouf $\left(33^{\circ} 25^{\prime} 38^{\prime \prime} \mathrm{N}, 9^{\circ} 02^{\prime} 08^{\prime \prime} \mathrm{E}\right)$ at the east of Chott ElDjerid (Fig. 3). This is an area where episodic rains drain fine alluvial material deposited in a succession of crust-like clay layers, alternated with intermediate fine sand from Aeolian origin (Fig. 4). This type of soil has the highest efficiency for Aeolian emissions (Marticorena et al., 1997).

The size distribution of soil-derived aerosols is completely different from that of soils in arid areas, composed of sands and silts, with modes between 100 and $700 \mu \mathrm{m}$ in diameter (Chatenet et al., 1996). At a certain distance from its source, soil-derived dust constitutes a coarse aerosol mode with a mass-median diameter (MMD) of 2 to 7 microns (see e.g. Dulac et al., 1989; Maring et al., 2003; Smolik et al., 2003). Such fine particles are produced during Aeolian erosion by a sandblasting process of clay aggregates by saltating 


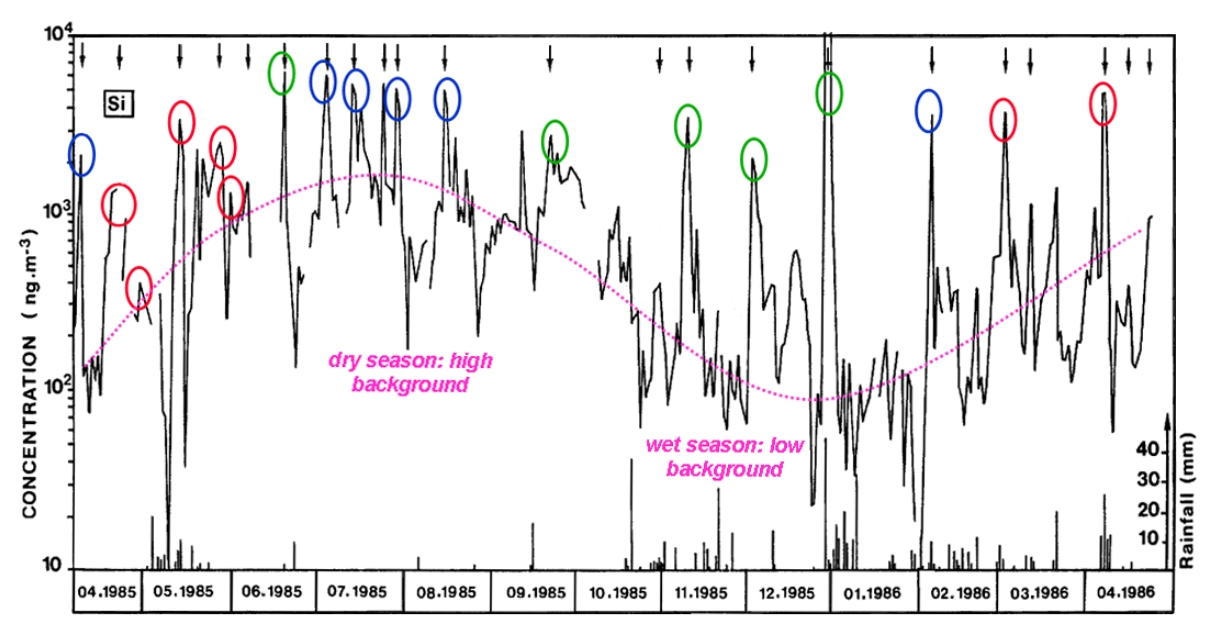

Fig. 2. Atmospheric concentration of particulate Si used as a tracer of African dust and rainfall as observed on a quasi daily basis in NW Corsica from April 1985 to April 1986. The pink dotted curve features the contrasted background between the dry and wet seasons in Corsica. Arrows indicate African dust outbreaks identified by air mass back-trajectories. When clearly identified, dust source regions are indicated by colored ovals: south of $30^{\circ} \mathrm{N}$ in red; Morocco-western Algeria in green; eastern Algeria-Tunisia-western Lybia in blue (after Bergametti et al., 1989).

sand grains (Gomes et al., 1990), and the aerosol production efficiency increases with the fraction of clay in the soil (Marticorena et al., 1997). In order to reproduce fine, long-range transported desert dust particles, we sampled a soil rich in clay minerals in an Aeolian aerosol source area, and we reproduced the effects of sandblasting and sedimentation by grinding and dry-sieving clay aggregates from the soil. Only the fraction $<20 \mu \mathrm{m}$ was considered for the seeding experiments.

We collected several tens of $\mathrm{kg}$ of soil using cleaned plastic material for collection and storage, and by selecting clay layers below the superficial sand voile or sand layer. Free sand was also collected separately. To avoid any contamination from metals, all subsequent manipulations of the soil material were performed using clean plastic or plastic-coated materials, including Nylon ${ }^{\circledR}$ meshes for sieving. We cleaned and thoroughly rinsed materials that were in direct contact with soil in $0.2 \mathrm{~mol} \mathrm{~L}^{-1}$ suprapure $\mathrm{HCl}$ acid baths and Milli$\mathrm{Q}^{\circledR}$ water.

After collection, we found that a first sieving step with a $3 \mathrm{~mm}$ mesh was effective in eliminating all free sand and at keeping only the crusted clay pieces for further processing. We then dried the soil in $1 \mathrm{~L}$ buckets at $105^{\circ} \mathrm{C}$ for $24 \mathrm{~h}$. The water content of samples was on the order of a few percent except for pure sand $(0.6 \%)$. Once dried, the soil was crushed with an agate pestle. All small organic debris and small roots seen during grinding were discarded with plastic or PTFEcoated tools.

The size distribution of an aliquot of the free sand was determined using a 12-stage column of standard metal meshes $(630,500,400,315,250,160,125,100,63,50,20$, $<20 \mu \mathrm{m})$ and fitted to a lognormal distribution with a $\chi^{2}$ fitting procedure (Chatenet et al., 1996). The sand was found to be very fine and extremely sieved by Aeolian transport with a MMD of about $75 \mu \mathrm{m}$ and a geometric standard deviation of about 1.2. Following a compromise between the decrease with particle size of cohesive forces and the increase in size of gravity forces, this mode is in the range of the most easily-mobilized particles by the wind (Marticorena and Bergametti, 1995). An interesting consequence of this size distribution is that a mesh at $40 \mu \mathrm{m}$ would be able to retain more than $99.9 \%$ of the sand. The same procedure was applied to a sample of ground clay. It showed a bimodal distribution with the two modes, each accounting for about half of the total: the narrow mode of the Aeolian sand and a broader mode of smaller particles with a MMD of about $40 \mu \mathrm{m}$ and a geometric standard deviation of about 1.9, likely dominated by clayey aggregates.

We then produced the fine particles by an intense drysieving (at least one hour and up to one night on the vibrating column at the maximum energy allowed by the system) of the crushed clayey material using a column of 3 Nylon ${ }^{\circledR}$ meshes of 100, 40 and $20 \mu \mathrm{m}$ (Fig. 5). We kept the finest fraction of soil particles $(<20 \mu \mathrm{m})$ since dust particles larger than $20 \mu \mathrm{m}$ are rapidly removed during atmospheric transport (Maring et al., 2003). The basic hypothesis is that the laboratory mechanical action of crushing and sieving has an equivalent effect of breaking the aggregates as the mechanical action of saltation and sandlasting under the action of the wind. It was found necessary to clean the meshes with a brush, or if necessary, by using water between samples to avoid clogging. The fine particle production efficiency ranged between 5 and $15 \%$ relative to the initial crushed material. This processing was performed at IRA in South Tunisia. It is worth noting 


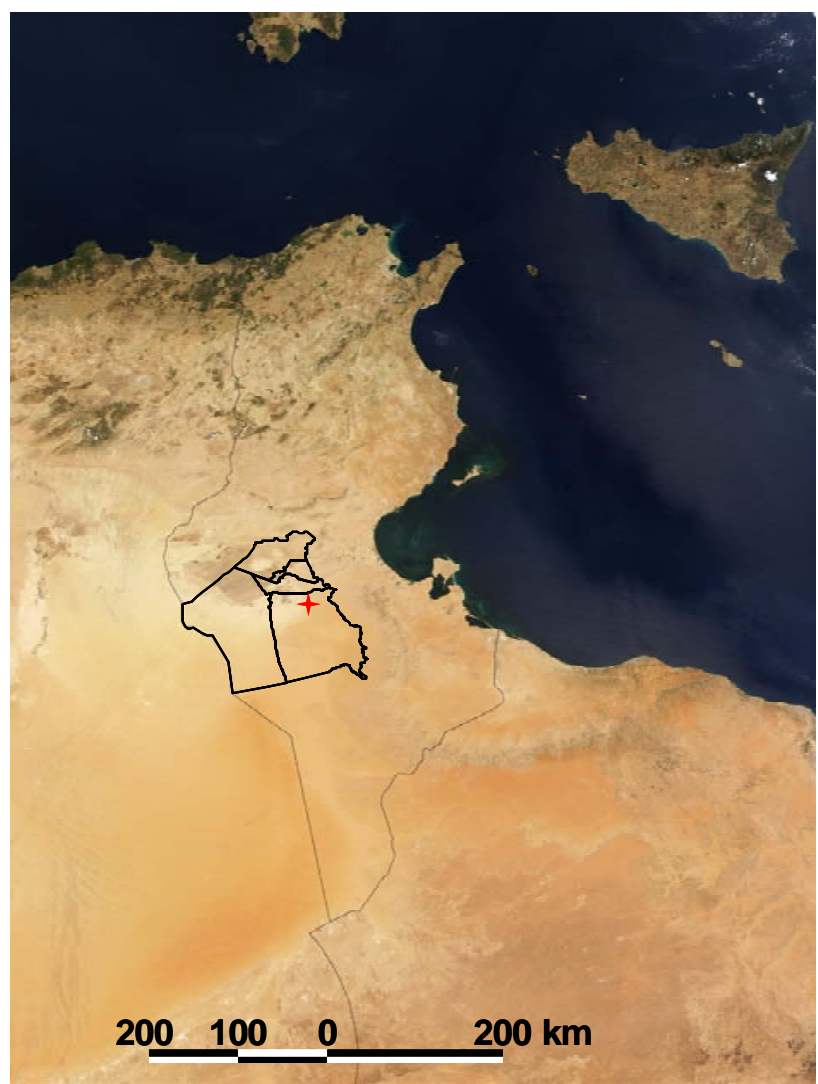

Fig. 3. MODIS satellite view of Tunisia with indications of national borders (credit: Jacques Decloitres, NASA/GSFC/Land Rapid Response Team) and districts of the Governorate of Kebili (bold line). The soil collection location $\left(33^{\circ} 27.7^{\prime} \mathrm{N}, 9^{\circ} 20.8^{\prime} \mathrm{E}\right)$ is marked by the red star in the district of Douz, SW of the Chott El Djerid (darker area) and at the NE margin of the Great Eastern Erg.

that we tentatively performed the same processing at LISA near Paris, but it turned out that we obtained only a very small production efficiency. We have no clear explanation but speculate that differences in relative humidity might have played an important role. The analysis by IRA of an aliquot of the fraction below $<100 \mu \mathrm{m}$ indicated a soil $\mathrm{pH}$ of 7.9 and an organic content of about $2 \%$.

\subsection{Aging the dust}

Due to the concomitance of dust and polluted air masses in the Mediterranean basin, the mixing between dust and anthropogenic pollution seems to be a usual process: direct observations using analytical electron microscopy of Mediterranean individual aerosol particles report, for example, an abundance of sulphate particles mixed with dust and their association with calcium in the form of gypsum $\left(\mathrm{CaSO}_{4}\right)$, which has been attributed to in-cloud reactions (e.g. Levin et al., 2005; Kalderon-Asael et al., 2009). Many other studies conducted in the Mediterranean have highlighted this

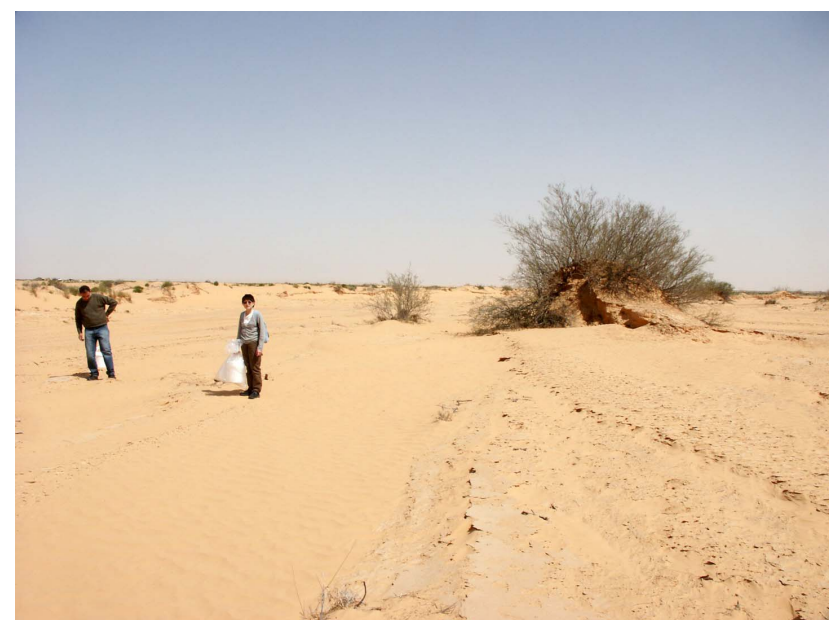

Fig. 4. Photo of the soil sampling area in the dry bed of Oued El Hallouf. In the centre of the front plan are visible clearer rests of clay deposits uncovered by the more orange sand (photo F. Dulac).

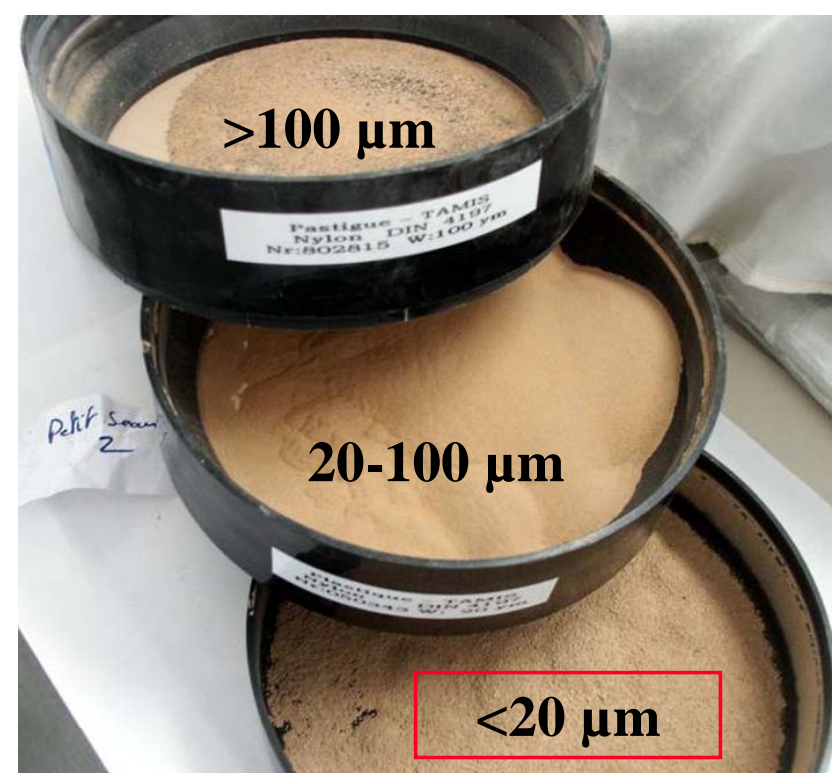

Fig. 5. Soil collected on the three stages of the dry sieving column at the end of the fine particle production process. The relative colors are indicative of the respective content: the upper stage $(100-\mu \mathrm{m}$ mesh) retains small organic debris (black grains), the largest sand grains and possibly clay aggregates; the intermediate stage $(20-\mu \mathrm{m}$ mesh) which contains about $3 / 4$ of the total mass contains mostly the fine, orange-yellowish colored, sand mode and a fraction of aggregated clay; the bottom stage contains the light brown-yellowish, finest fraction of disaggregated particles, dominated by clay (photo F. Dulac).

association, which is attributed to the heterogeneous reaction of gaseous $\mathrm{H}_{2} \mathrm{SO}_{4}$ with the surface of $\mathrm{CaCO}_{3}$ mineral particles (e.g., Formenti et al., 2001; Falkovich et al., 2001). A significant interaction between $\mathrm{HNO}_{3}$ and dust was also observed in both the western and eastern Mediterranean basins 
(Putaud et al., 2004; Koçak et al., 2007). Laboratory studies on heterogeneous chemistry have shown that the Ca content of particles is a paramount parameter explaining their reactivity (e.g. Krueger et al., 2004), partly because their hygroscopicity is increased. From samples collected during episodes of transport of northern African mineral dust to Israel, Falkovich et al. (2001) indicated that organic material could also be internally mixed with mineral dust. Aymoz et al. (2004) also detected various organic acids (including oxalic acid) in the aerosol coarse mode over the Alps and suggested some uptake of organic acidic gases during transport. The dust uptake of secondary acids $\left(\mathrm{H}_{2} \mathrm{SO}_{4}\right.$ or $\left.\mathrm{HNO}_{3}\right)$ or organic compounds is likely to be the main factor for the enhancement of solubility and hence the bioavailability of nutrients in dust particles during atmospheric transport (Jickells et al., 2005; Anderson et al., 2010). Solmon et al. (2009) concluded, for example, that $30 \%$ to $70 \%$ of particulate soluble iron over the North Pacific Ocean basin could be attributed to atmospheric processing. In the same way, mineral dust mixed with nitrate is also an important vector for nitrogen fertilization of surface oceans (Baker et al., 2003).

The South Tunisian source region is known to produce calcium-rich dust (Bergametti, 1987; Avila et al., 2007) due to carbonated lithology of soils in this region (Claquin et al., 1999). The calcium index of dust shows high calcite concentrations in the dust originating from Tunisia, northern and central Algeria, and Morocco, and low concentrations south of approximately $27^{\circ} \mathrm{N}$ (Kandler et al., 2007). Desboeufs and Cautenet (2005) emphasized that the Tunisian dust had a high potential for mixing with anthropogenic pollutant over the Mediterranean Sea due to their calcite content. Consequently, we chose to mimic this atmospheric uptake of inorganic and organic soluble species on dust during transport via an in-cloud reaction. Our approach to aging dust is based on previous works from Desboeufs et al. (2001), enabling the laboratory simulation of cloud evapocondensation cycling for small amounts of dust $(\sim 1 \mathrm{~g})$, which reproduces the photochemistry and the gradients in $\mathrm{pH}$ and ionic strength during cloud processing of dust particles. The procedure was adapted to processing the large amount of dust necessary for the DUNE seeding experiments while working with dust loading that corresponds to natural conditions. This simulation consists of mixing dust with synthetic cloud water (see next paragraph) in a bottle (condensation step), then spreading the suspension on a polystyrene tray $\left(32.5 \times 44.5 \mathrm{~cm}^{2}\right)$ and evaporating the aqueous phase under clean air flux (Fig. 6). This approach is performed inside a clean room, and all material used during the process is cleaned using ultraclean protocols for trace metals (Losno et al., 1991).

To our knowledge, no information on the chemistry of cloud droplets in the presence of dust is available for the Mediterranean. The choice of "cloud water" conditions for the condensation step was based on the work of Meskhidze et al. (2003). They calculated from rainwater data (East
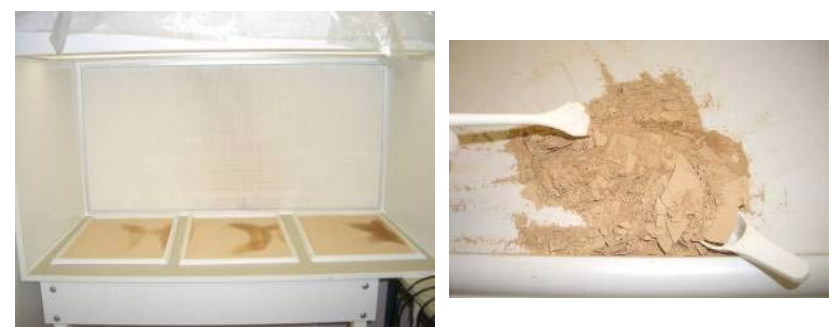

Fig. 6. Artificial aging of the atmospheric particles. The principle is to quickly evaporate a water-aerosol mixing in the typical proportions of a cloud drop that is deposited on ultraclean polypropylene plates under clean air within a laminar flow bench. Water is amended with substances normally observed in Mediterranean marine atmosphere. The added aerosols are the finest fractions of the dust collected in Tunisia. The evaporation leads to a $\mathrm{pH}$ gradient in the system induced by proton concentration related to decrease in water volume, exactly as it occurs inside a cloud (photo S. Tran).

Asia) that, during mixing in cloud process, the $\mathrm{pH}$ around dust could be very low (around 1) due to the large amount of dissolved acid and to the low water quantity, explaining the observed values of nitrate on dust. From this calculation and from the actual concentration of sulphate and nitrate measured in rain collected in the western Mediterranean area (Löye-Pilot and Morelli, 1988; Quereda Sala et al., 1996; Balestrini et al., 2000; Muselli et al., 2002; Aiuppa et al., 2003; Loÿe-Pilot et al., 2005; Avila et al., 2007), we estimated a dust/water ratio content in Mediterranean evaporating cloud water at around 10000 . We worked with a high dust loading in water of $100 \mathrm{~g} \mathrm{~L}^{-1}$, corresponding to 10000 times the typical "desert" rain event $\left(10 \mathrm{mg} \mathrm{L}^{-1}\right.$; Ridame et al., 2002). As a consequence all of the concentrations have been multiplied by a factor 10000 in order to remain within the same ratio of concentrations as is found in natural rainwater. Apart from the inorganic acid species, we also considered the presence of oxalic acid in the aging simulation, which is the major organic acid found in the Mediterranean rain waters and aerosols (Peña et al., 2002; Bardouki et al., 2003; Aymoz et al., 2004) and which is known to enhance the dissolution of iron (Cwiertny et al., 2009; Paris et al., 2010). Table 1 summarizes the average composition of "desert" rain concentrations used as a reference and the concentrations used for our simulation. Preliminary dissolution tests of the Tunisian fine soil fraction showed that it was little influenced when simulated solar light was applied. Consequently, no added light has been used during the cloud cycling simulation. From this cloud cycling protocol (summarized in Table 1), $250 \mathrm{~g}$ of the fine fraction of Tunisian soil was processed and stored in a clean container. This processed dust is named hereafter as "evapocondensed dust" or "dust EC"; original dust will be referred to as "dust non-EC". 
Table 1. Chemical composition of (1) desert dust-loaded rains in the Mediterranean environment and (2) simulated Mediterranean cloud water.

\begin{tabular}{lcccr}
\hline & $\begin{array}{c}\mathrm{pH} \text { without } \\
\text { buffering } \\
\text { effect by } \\
\text { carbonates }\end{array}$ & $\begin{array}{c}{\left[\mathrm{SO}_{4}^{2-}\right]} \\
(\mathrm{M})\end{array}$ & $\begin{array}{c}{\left[\mathrm{NO}_{3}^{-}\right]} \\
(\mathrm{M})\end{array}$ & $\begin{array}{r}{\left[\mathrm{C}_{2} \mathrm{O}_{4}^{2-}\right]} \\
(\mathrm{M})\end{array}$ \\
\hline $\begin{array}{l}\text { Average of } \\
\text { referenced } \\
\text { Saharan } \\
\text { rains* }\end{array}$ & 4.7 & $10^{-5}$ & $10^{-5}$ & $6.10^{-6}$ \\
$\begin{array}{l}\text { Simulated } \\
\text { cloud } \\
\text { water }\end{array}$ & 0.7 & $10^{-1}$ & $10^{-1}$ & $1.810^{-2}$ \\
\hline
\end{tabular}

* Löye-Pilot and Morelli (1988), Querada Sala et al. (1996), Balestrini et al. (2000), Peña et al. (2002), Muselli et al. (2002), Aiuppa et al. (2003), Loÿe-Pilot et al. (2005), and Avila et al. (2007)

\subsection{Dust characterization}

Both non-processed and evapocondensed dust types were used for the mesocosm experiments. In order to compare the responses obtained in both cases, an exhaustive physicochemical characterization of both dust samples was carried out before seeding, including particle size distribution, chemical and mineralogical composition.

\subsubsection{Size distribution}

Particle size analysis was performed from liquid suspension of Tunisian dust by employing a laser technique based on the laser obturation time of transition (TOT) theory (De Falco et al., 1996; Weiner et al., 1998; http://www. ankersmid.com/AF/Laser.Obscuration.Time.Technique/) using an Ankersmid EyeTech CIS-1 multichannel particle size analyzer equipped with an ACM-101 magnetic stirring measurement cell. The measuring particle diameter $(D)$ range is $0.04-2000 \mu \mathrm{m}$. Channels have a constant size resolution in logarithmic scale $\left(\log _{10}(D) \approx 0.0405\right)$. The water suspension was first ultrasonically and mechanically agitated to break up any aggregate. Sub-samples of $2 \mathrm{~mL}$ each were then taken from the same agitated sample and transferred into sample cells. A small magnetic spin bar in each sample cell stirred the solution to prevent particles from settling. To ensure good data quality, we imposed a measurement confidence level of $95 \%$ in both number and volume size distribution. The confidence level is the probability that the measured mean size of the sample particles is within $\pm 2.5 \%$ of the true mean. Hence, the instrument continued scanning the sample until this confidence level was reached.

The volume size distribution of non-processed dust and evapocondensed dust are quasi-identical (Fig. 7a). The
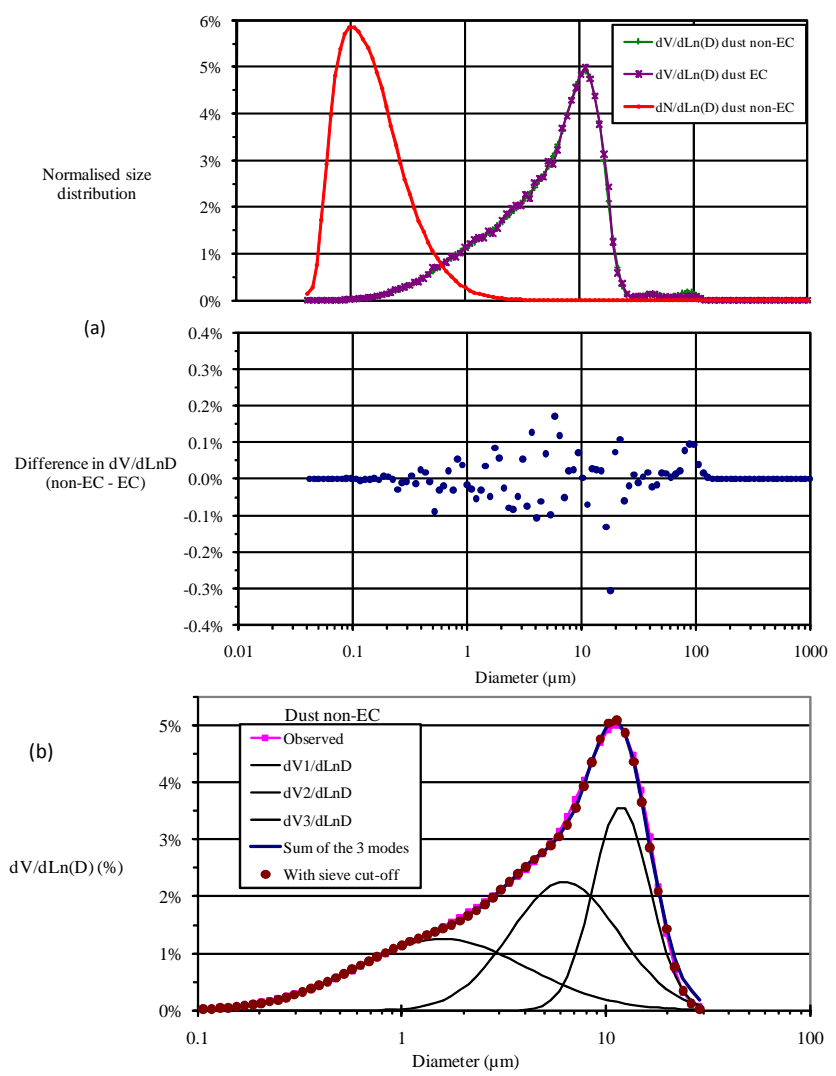

Fig. 7. (a) Normalised particle volume size distributions of nonprocessed and evapocondensed dust and absolute difference between the two distributions (below); (b) fit of the size distribution with a sum of 3 lognormal modes and assuming a cut-off of the $20-\mu \mathrm{m}$ mesh (see text).

sieving mesh of $20 \mu \mathrm{m}$ produces a clear cut-off of the particle size distribution, but it appears that the cut-off efficiency of the $20-\mu \mathrm{m}$ mesh of the sieve is higher at $30 \mu \mathrm{m}$ than at $20 \mu \mathrm{m}$. The spectra present a volume median diameter around $6.5 \mu \mathrm{m}$ and a peak at $\sim 10 \mu \mathrm{m}$. A large body of observations of the column-integrated particle volume size distribution during dust outbreaks in the Mediterranean is available (Tomadin et al., 1984; Dulac et al., 1989; Kubilay et al. 2003; Masmoudi et al., 2003; Derimian et al., 2006; Tafuro et al., 2006). The presence of coarse particle modes in desert aerosols was clearly pointed out by these authors, with a particle diameter mass or volume peak value generally within the $2-8 \mu \mathrm{m}$ range. This was also observed elsewhere (see for instance the compilation in Reid et al., 2003). Reid et al. (2003) concluded that larger modal diameters $(\sim 9-13 \mu \mathrm{m})$ observed for coarse dust aerosol particles with optical particle counters resulted from methodological biases.

There is little evidence from dry and wet deposition samples that particles greater than $\sim 8-10 \mu \mathrm{m}$ control both the dry (Dulac et al., 1989, 1992) and wet deposition fluxes (Pitty, 1968; Dulac, 1986; Guerzoni et al., 1993; De Falco 
et al., 1996). Consequently, the size distribution of our dust analogue appears shifted to large values when compared to dust transported over the Mediterranean, yet appears more representative of the size distribution of deposited dust.

We could adjust the sum of three lognormal modes to the volume size distribution (up to $30 \mu \mathrm{m}$ in diameter) by minimizing a $\chi^{2}$ using the Microsoft Excel solver (Fig. 7b). To remove the tail of the fitted distribution towards large particles, which caused an excess of particles larger than $20 \mu \mathrm{m}$ in diameter in the fitting procedure, we accounted for a cut-off efficiency of the 20- $\mu \mathrm{m}$ sieving mesh that linearly increased from 0 at $20 \mu \mathrm{m}$ to 1 at $30 \mu \mathrm{m}$. We ended up with three modes of roughly the same total volume (30-36\% each) and with the following respective volume-median diameters (VMD): $\mathrm{VMD}_{1} \sim 1.6 \mu \mathrm{m}, \mathrm{VMD}_{2} \sim 6.2 \mu \mathrm{m}$ and $\mathrm{VMD}_{3} \sim 12 \mu \mathrm{m}$ (geometric standard deviations are $\sim 2.6, \sim 1.8$ and $\sim 1.4$, respectively). It is striking to note that these modal diameters roughly corresponded to those of the three mineral aerosol modes that were observed to be produced by wind erosion of arid soils (mass-median diameters of 1.5, $~ 6.5$ and 12$16 \mu \mathrm{m}$; Alfaro et al., 1998).

Figure $7 \mathrm{a}$ also presents the particle size distribution expressed in number concentration. The distribution peaks at $0.1 \mu \mathrm{m}$, and has a median and mean diameter 0.22 and $0.32 \mu \mathrm{m}$, respectively. This implies that about half of the particles passed through the $0.2-\mu \mathrm{m}$ porosity filters used to separate soluble and particulate phases in seawater such that associated chemical elements were accounted for in the dissolved phase. Such small particles carried less than $1 \%$ of the total dust mass but may have impacted the assessment of the soluble fraction in seawater for low-solubility elements, such as iron. Finally, the particle size distribution in number concentration of our dust analogue shows that $99 \%$ of the particles were below $1 \mu \mathrm{m}$ in diameter, which means that they have a very weak settling velocity in seawater if they are not self-aggregating to form larger particles or if they are not embedded in, or adsorbed by, larger biogenic aggregates.

\subsubsection{Mineralogical composition}

Step-scan X-ray powder-diffraction data for the samples were retrieved over a $2 \theta$ range of $3-80^{\circ}$ with Co $K-\alpha$ radiation on a standard Siemens (Bruker) D5000 BraggBrentano diffractometer equipped with a Fe monochromator foil, 0.6-mm $\left(0.3^{\circ}\right)$ divergence slit, incident- and diffractedbeam Soller slits and a Vantec-1 strip detector. The long finefocus Co X-ray tube was operated at $35 \mathrm{kV}$ and $40 \mathrm{~mA}$, using a take-off angle of $6^{\circ}$. Mineral identification was done using the International Centre for Diffraction Database PDF-4 and Search-Match software by Siemens (Bruker). This analysis is semi-quantitative due to, most notably, the low volume of supplied dust for the analysis.

The results showed the dominance of quartz (40\%) and calcite $(30 \%)$ was followed by clays $(25 \%)$. The clay fraction was composed mainly of illite and kaolinite and included palygorskite at trace level, which is a typical mineral of Northern Sahara (Formenti et al., 2008). Dolomite was also detected.

\subsubsection{Chemical composition}

The elemental composition of the particles was obtained by both Wavelength Dispersive X-ray fluorescence (WD-XRF) and high-resolution Inductively Coupled Plasma-Mass Spectrometry (HR-ICP-MS) after acid digestion. WD-XRF analyses were performed using a PW-2404 spectrometer by Panalytical. Excitation $\mathrm{X}$-rays were produced by a Coolidge tube $\left(I_{\max }=125 \mathrm{~mA}, V_{\max }=60 \mathrm{kV}\right)$ with a Rh anode; the primary $\mathrm{X}$-ray spectrum can be controlled by inserting filters (Al, at different thickness) between the anode and the sample. Each element was analyzed three times, with specific conditions (voltage, tube filter, collimator, analyzing crystal and detector), lasting 8 to $10 \mathrm{~s}$. Two types of analyses were carried out on the dust by WD-XRF, a first analysis using borate glass discs (Quisefit et al., 1994) and a second using deposition on a filter (Quisefit and Randrianarivony, 1998). The elemental analysis by ICP-MS was performed following the method developed by Pretorius et al. (2005). Dust was decomposed in high-pressure containers using $\mathrm{HF}-\mathrm{HNO}_{3}-\mathrm{HClO}_{4}$, and sample solutions were then subsequently dried and dissolved again in $1 \% \mathrm{v} / \mathrm{v} \mathrm{HNO}_{3}$ for direct measurement with HR-ICP-MS. A double-focusing sector field Element2 ICPMS (Thermo Finnigan, Bremen, Germany) associated with a conventional Teflon PFA spray chamber, $100 \mu \mathrm{L} \mathrm{min}^{-1}$ microflow Teflon PFA nebuliser and saphire injector were used. Finally, total concentrations of carbon (TC) and nitrogen were measured in triplicate with a LECO900 elemental analyzer (CHN) at LOV, on aliquots of the desiccated samples (3-4 mg).

The chemical composition (Table 2) agreed with the results obtained on the mineralogical composition. The dominant $\mathrm{Ca}$ content was directly related to the presence of calcite in the samples and agreed with literature data on the chemistry of Tunisian dust (e.g. Avila et al., 2007). Si/Al ratio was 3.75, which was higher than the average mass ratio typically measured in mineral dust (3, see e.g. Formenti et al., 2008), indicating a small enrichment of the sample by quartz when compared to typical African dust. With regard to $\mathrm{Fe}$ and $\mathrm{P}$, their concentrations were comparable with available Saharan dust data (Guieu et al., 2002; Formenti et al., 2008).

The comparison between non-processed and evapocondensed dust shows a similar chemical composition except for $\mathrm{S}$ and $\mathrm{N}$, and to a lesser extend for $\mathrm{C}$. The strong comparison for trace elements such as $\mathrm{Cu}$ and $\mathrm{Co}$ enables us to conclude that there was no contamination of the dust during the experimental aging process. The $\mathrm{S}$ and $\mathrm{N}$ contents were increased by a factor 130 and 10 , respectively, by the simulated cloud water processing. This result is consistent with the mixing of dust and sulphate and nitrate observed over the Mediterranean (as mentioned above) that we intended to 
Table 2. Elemental composition of non-processed dust and evapocondensed dust.

\begin{tabular}{lrrrr}
\hline & $\begin{array}{r}\text { Non processed } \\
\text { Dust }\end{array}$ & $( \pm)$ & $\begin{array}{r}\text { Evapocondensed } \\
\text { Dust }\end{array}$ & $( \pm)$ \\
\hline$\% \mathrm{Ca}$ & $18.62 \%$ & $0.33 \%$ & $17.95 \%$ & $1.22 \%$ \\
$\% \mathrm{Si}$ & $15.16 \%$ & $0.93 \%$ & $13.59 \%$ & $1.64 \%$ \\
$\% \mathrm{C}$ & $6.75 \%$ & $0.01 \%$ & $5.35 \%$ & $0.06 \%$ \\
$\% \mathrm{Al}$ & $4.48 \%$ & $0.12 \%$ & $4.12 \%$ & $0.39 \%$ \\
$\% \mathrm{Fe}$ & $2.28 \%$ & $0.19 \%$ & $2.31 \%$ & $0.04 \%$ \\
$\% \mathrm{Mg}$ & $1.85 \%$ & $0.17 \%$ & $1.72 \%$ & $0.28 \%$ \\
$\% \mathrm{~K}$ & $1.19 \%$ & $0.08 \%$ & $1.15 \%$ & $0.20 \%$ \\
$\% \mathrm{Ti}$ & $0.33 \%$ & $0.03 \%$ & $0.33 \%$ & $0.03 \%$ \\
$\% \mathrm{~N}$ & $0.11 \%$ & $0.01 \%$ & $1.15 \%$ & $0.03 \%$ \\
$\% \mathrm{P}$ & $0.04 \%$ & $0.01 \%$ & $0.05 \%$ & $0.01 \%$ \\
$\% \mathrm{Mn}$ & $0.035 \%$ & $0.002 \%$ & $0.035 \%$ & $0.005 \%$ \\
$\% \mathrm{~S}$ & $0.012 \%$ & $0.001 \%$ & $1.54 \%$ & $0.01 \%$ \\
$\% \mathrm{Cu}$ & $0.0015 \%$ & $0.0003 \%$ & $0.0015 \%$ & $0.0003 \%$ \\
$\% \mathrm{Co}$ & $0.0011 \%$ & $0.0002 \%$ & $0.0008 \%$ & $0.0003 \%$ \\
\hline
\end{tabular}

mimic. The $\mathrm{S}$ and $\mathrm{N}$ enrichment was probably associated with the reactivity of calcite with the inorganic acid $\mathrm{H}_{2} \mathrm{SO}_{4}$ and with $\mathrm{HNO}_{3}$ added in the simulated cloud water. During the evaporation step, dissolved calcium reacts with sulphate and nitrate and forms $\mathrm{CaSO}_{4}$ and $\mathrm{Ca}\left(\mathrm{NO}_{3}\right)_{2}$ to the detriment of the calcium carbonate, whose content should decrease in the sample (Gibson et al., 2006). These results display that, in the same proportion, sulphate seems to be more reactive with calcite than nitrate, contrary to the observations of Hwang and Ro (2006). Thus, the loss of $20 \%$ of C could have resulted from a combination of the removal of carbonates species due to reactivity with inorganic acids and from enrichment due to the formation of oxalate salts in surface of dust.

Finally, we have shown that our strategy for producing a large amount of dust that can be used for seeding large mesocosms was appropriate, as the physico-chemical composition of the obtained dust was comparable to actual aerosols collected in the Mediterranean environment. Evapocondensed dust is comparable to Saharan dust that mixes with airmasses that have been influenced by anthropogenic activity. Non-processed and evapocondensed dust were used in two different seeding experiments during DUNE-1.

\section{The marine experimental platform}

In LNLC waters, the concentrations of both nutrients and micronutrients are expected to be at nanomolar levels. Therefore, extreme caution was necessary in designing the different aspects of the mescoscosm experiment in order to avoid any type of contaminations during all steps (building, deployment, mooring, filling, seeding, sampling etc.). The terms of reference were that all the parts had to be made of plastic, be transportable to the site with a small boat, and that the setup allowed maximum light to reach seawater inside the mesocosms. The specificities of DUNE (fertilization by atmospheric input, studies of trace metals and low level nutrients) drove our choices regarding (1) the material and the shape of the bags, (2) the design of a holding structure and (3) the sampling system. In fact, the methodologies currently used by the scientific community concerning mesocosms had to be adapted for our specific objectives. We started from an existing design developed by J. Seppälä (see for ex. Olli and Seppälä, 2001).

\subsection{The bags}

The selected mesocosms consisted of large bags made of two $500-\mu \mathrm{m}$ thick films of polyethylene mixed with vinyl acetate (EVA, 19\%) with nylon meshing in between to allow maximum resistance and light penetration (HAIKONENE KY, Finland). They were $2.3 \mathrm{~m}$ in diameter and $12.5 \mathrm{~m}$ in height for the cylindrical part, and $2.2 \mathrm{~m}$ for the conical part at the bottom (surface is $4.15 \mathrm{~m}^{2}$ and total volume $52 \mathrm{~m}^{3}$ ). The conical bottom ended with a $3^{\prime \prime}$ adapter that allowed the fastening of a small trap to collect the sinking material. This original design was modified as follows to meet our goal. Filling the bags is a crucial step and is typically performed by large volume pumps since the bottom opening is small and precludes rapid filling (see for ex. Schulz et al., 2008). The two existing options (large volume pumps or slow natural filling from below) were not employed in our study because both can significantly modify the structure of the surface waters and also contaminate the inside water. Our solution was to build the bags in two parts (Fig. 8): (1) a main cylinder (2.3 m diameter) ending with a diameter reduced to $1.5 \mathrm{~m}$ and (2) a cone. At the bottom of the main cylinder and at the top of the cone, two PVC circles $(8 \mathrm{~cm}$ in width) were installed, thereby sandwiching the plastic. The two were held tightly together by 8 nylon screws, which created a strong bond between the two parts. One cannot overlook the possibility of some amount of water exchange between inside and outside of the mesocosm via the junction between the two parts, even if the PVC circles were tightly screwed. However, if it occurred, this would have concerned an extremely small water volume, as there is no pressure gradient between the inside and the outside of the mescosm.

Even though the site where the mesocosms were deployed was protected from the dominant winds (SW sector) in the area, the site was subjected to frequent winds from other directions. Further, swell and currents can be significant inside the Elbo Bay (Romano et al., 2006). Such conditions could have deformed the bags or even torn the plastic material, in particular in the above part of the mesocosm that was subjected to the strongest strain. In order to strengthen the system and to well maintain the cylindrical shape for the duration of the experiment, large rings made from PE tubes (diameter $=40 \mathrm{~mm}$ ) were installed at five different levels inside 


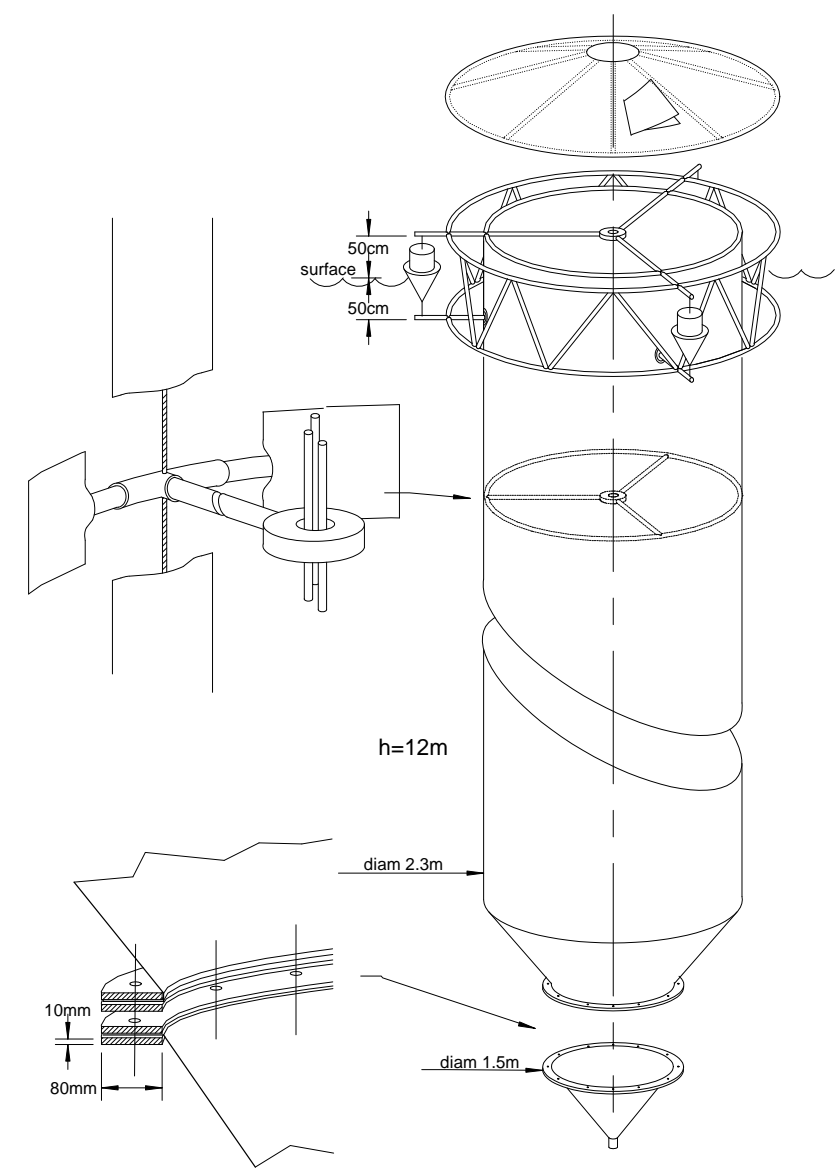

Fig. 8. Drawing representing the main features of the large-clean mesocosm device. The cone at the bottom is installed under water by two divers $24 \mathrm{~h}$ after the top piece has been deployed from the surface: the two PVC sandwiches are joined with plastic screws.

horizontal tunnels which were made with the same plastic material and thermo and glued inside the main cylinder (Fig. 8). At three points on each of the PE rings, the same PE tube material was used to attach the interior of the ring to a custom-designed PVC part placed at the center of the bag (Fig. 8). This centerpiece had two functions: it creates a wire wheel that maintained the round shape of the bag, and it centered the sampling tubing (see Sect. 4.3).

In order to exclude the possibility that a "real" Saharan event could disturb the experiment, the mesocosms were covered. The cover was designed in order to let the maximum light reach the body of water inside the mesocosm, and transparent PVC material was used. Prior measurements of the absorption spectrum (J. Ras, personal communication, 2007) have indicated that this PVC material absorbs light in the UV wavelengths but not in the visible wavelengths. These covers were elevated to $10 \mathrm{~cm}$ above the top of the mesocosms, allowing air to circulate in order to avoid a confinement effect in the trapped water.
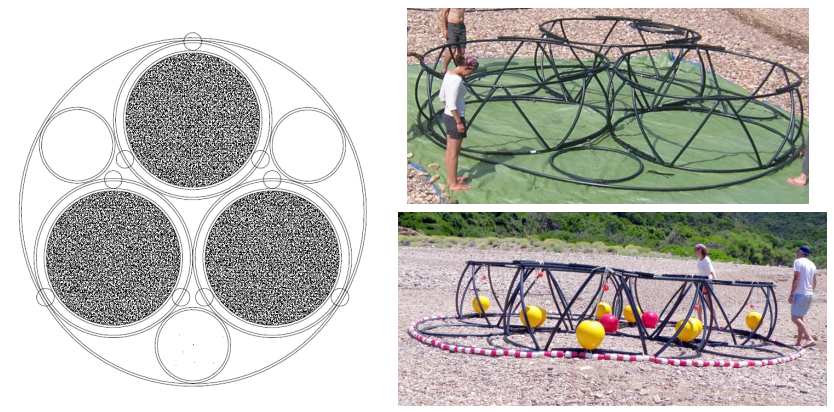

Fig. 9. Design of each PE structure holding 3 mesocosms (photo C. Ridame).

\subsection{The holding structure}

For the purpose of our seeding experiment, six mesocosms were needed. We decided to design and assemble two PE structures that would be able to hold three mesocosms receiving the same treatment (Fig. 9). The bags were held inside the PE structure at three points thanks to PVC cylindrical structures at the level of the upper ring and at the level of the ring just below the surface of the sea: this allowed us to avoid having tension applied directly to the bags. The structures were moored using only non-metallic material (except for the screw anchors installed at the sea floor $25-30 \mathrm{~m}$ deep). Each structure was moored using three anchor screws installed at $120^{\circ}$ of each other and connected to sub-surface buoys, which were themselves linked to surface buoys. The complete setup was a solid mooring capable of absorbing the sea swell while maintaining a supple and strong structure and ensuring that no tension was applied directly to the bags.

\subsection{Operation platform and sampling system}

All seeding and sampling operations in the mesocosms were performed from two mobile plastic platforms that were moved using several two-way ropes installed in between buoys. In between the two structures of three mesocosms, reference measurements were performed in free seawater. The protocol established to conduct the seeding experiment was aimed at minimizing the disturbance of the water column trapped inside the bags, and ensuring at least "simultaneity" for the deployment. An original sampling system was designed with the goal of inducing the least possible perturbation inside the mesocosms during sampling. In each bag, three clear, braided PVC tubing (Holzelock-Tricoflex, inside diameter $=9.5 \mathrm{~mm}$ ) were permanently installed at the center of the bags, with one end at three different depths: $10 \mathrm{~m}, 5 \mathrm{~m}$ and $0.1 \mathrm{~m}$. The other ends were fixed outside of the mesocosms. The sampling was done by pumping: a PFA pump (St-Gobain Performance Plastics) activated by the pressurized air from a diving tank was connected successively to the ends of the three tubing coming out of the mesocosm, 
allowing us to sample directly at the three selected depths without introducing any device inside. This system allowed us to sample water directly, either non-filtered or filtered (using different types of cartridges according to the parameter to be measured).

\subsection{Filling of the mesocosms}

Filling the mesocosms was done with the aim to reduce at minimum the risk of contamination. The main cylindric part of the mesocosms was first deployed: the bags, cinched by three small elastic ropes, had four small ballasts temporary attached to the PVC circle. They were placed inside the holding structure on the surface of the water. Once fixed to the holding structure at three places, the elastic ropes were released, allowing the main cylinder to gently, but rapidly ( $\sim 10 \mathrm{~min})$, deploy vertically with the assistance of one diver who stayed outside the bag at the level of the PVC circle. The entire operation of successively deploying the six bags (place on the surface, attach to the structure, and fill) took less than two hours. Once the main cylinder was deployed, it was left open for $24 \mathrm{~h}$ in order to stabilize the water mass inside. This step was also a way to remove possible particles that could have been stuck to the plastic from the time of its fabrication. After $24 \mathrm{~h}$, divers attached the conical bottom of the cylinder by screwing together the two PVC sandwiches (see Fig. 8 and Sect. 4.1). During the entire installation, the divers followed instructions to remain outside the bags in order to minimize disturbance of the waters, particularly from air bubbles. Figure 10 shows pictures of the entire setup, above and below the seawater level.

\section{Seeding experiments}

Two seeding experiments were conducted in June 2008. The first one (named hereafter experiment "DUNE-1-P"; duration 8 days, 11-18 June 2008) mimicked a wet deposition event using evapocondensed dust, and the second one (named hereafter "DUNE-1-Q"; duration 8 days, 20-27 June 2008) mimicked a dry deposition event using non-evapocondensed dust. For both $\mathrm{P}$ and $\mathrm{Q}$ experiments, the group of three seeded mesocosms is referred as "DUST-Meso" and the other group without dust as "CONTROL-Meso".

\subsection{Initial conditions}

The chlorophyll $a$ (Chl- $a$ ) concentration was typical of oligotrophic systems (of the order of $0.1 \mu \mathrm{g} \mathrm{L}^{-1}$ for both experiments). The dissolved inorganic phosphorus was close to, or below, the detection limit $(2 \mathrm{nM})$, which agrees with observations for summer conditions in open waters (DYFAMED time series; Pulido-Villena et al., 2010). The nitrate/nitrite concentrations were low, but detectable $(0.2 \mu \mathrm{M})$. Dissolved iron was on the order of $2.5 \mathrm{nM}$ at the beginning of both experiments. This was higher than typical concentrations in

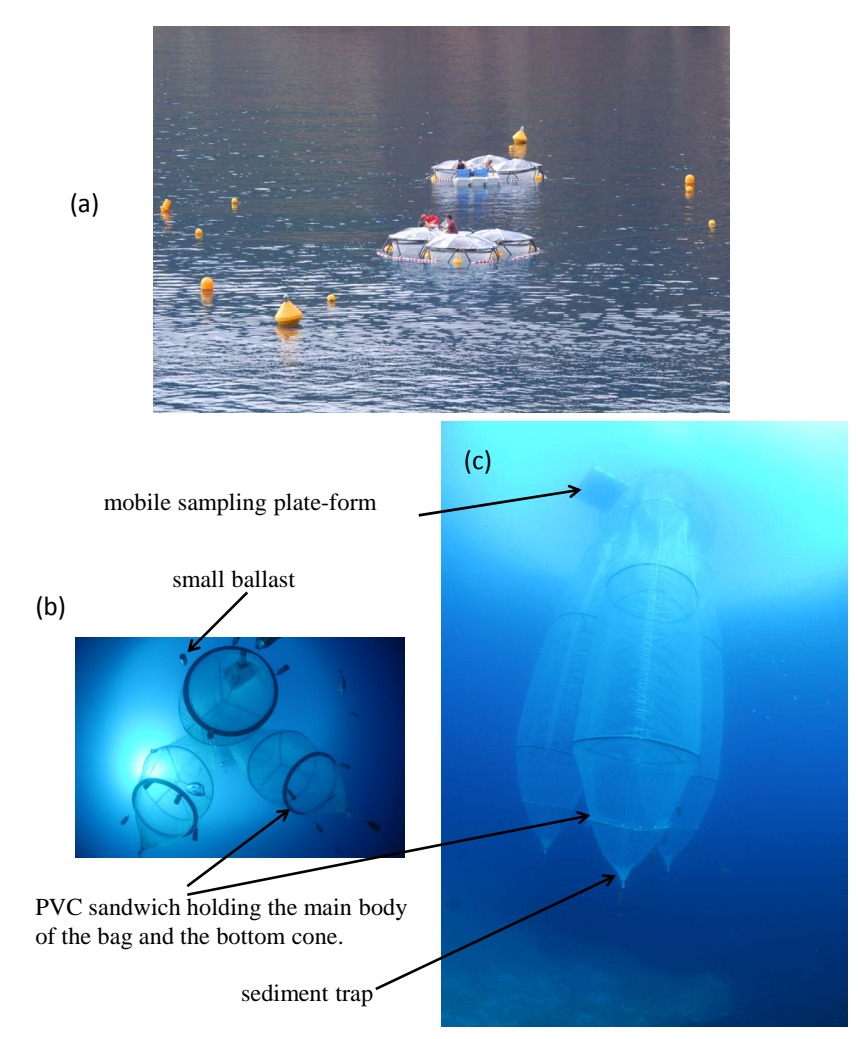

Fig. 10. (a) A view of the experiment from above: the two platforms in open waters separated by a few meters. At mid-distance between the two platforms is the position where the "OUTSIDE" sampling was performed. (b) A view from the seafloor showing the bases of three mesoscosms, in particular one can see the junction between the main body of the bag and the bottom cone created by the PVC sandwiches (photo: David Luquet, OOV). (c) A view from below, (from the side), of a group of three mesocosms; the seafloor is $10 \mathrm{~m}$ below the base of the mesocosms. At the surface, the plastic mobile platform moved temporarily close to the structure for sampling every day. At the base of the bags: the small sediment traps.

open sea waters of the NW Mediterranean Sea in late summer (e.g. Guieu et al., 2002; Bonnet and Guieu, 2006) and likely reflects a coastal influence (Wagener et al., 2010), but could also be due, to some extent, to a dust deposition that occurred in late May with a deposition flux on the order of $0.4 \mathrm{~g} \mathrm{~m}^{-2}$ (Dulac et al., 2010). While the seawater temperature during the entire DUNE-P experiment was in the range of 17$21.5^{\circ} \mathrm{C}$ and the stratification of the column water inside the mesocosms was not marked, it significantly increased during the DUNE-Q experiment with a range of $18.5-26^{\circ} \mathrm{C}$. As seen in Fig. 11, the air temperature during the day was stable during DUNE-P, with an average value of $23^{\circ} \mathrm{C}$. The air temperature increased rapidly at the beginning of the DUNE-Q experiment to attain an average daytime value of $29^{\circ} \mathrm{C}$. This rapid increase in air temperature led to the establishment of a thermal stratification of the surface waters. A shift from spring to summer conditions thus occurred between $\mathrm{P}$ and $\mathrm{Q}$ experiments. 


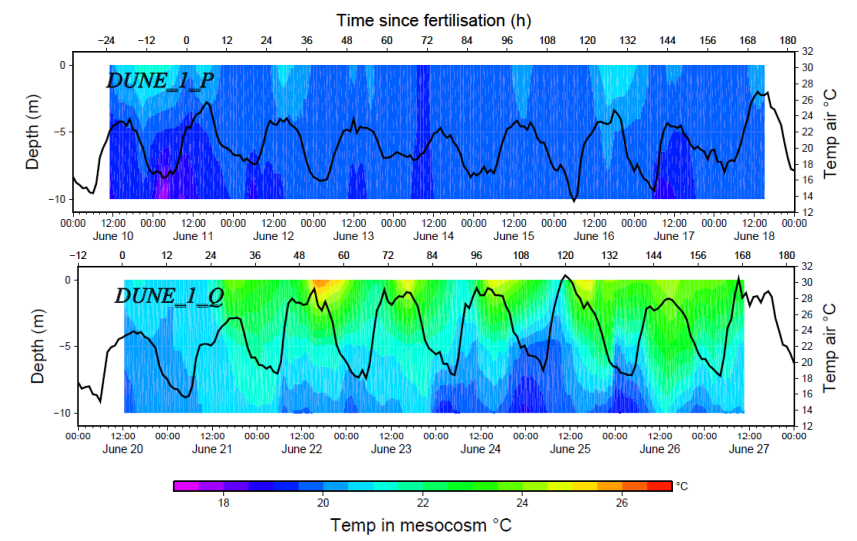

Fig. 11. Evolution of the seawater temperature profile from the surface down to $10 \mathrm{~m}$ during the DUNE1 campaign. Top: Pexperiment. Bottom: Q-experiment. The superimposed air temperature (black line) indicates how the day/night cycle clearly impacted the intensity of the stratification during the DUNE-Q experiment.

\subsection{Seeding the dust}

The dust was spread at the surface of the mesocosms using entirely plastic, 4-L (HD polyethylene) sprayers (only the sprayer extension was made of a carbon tube): these devices were acid-cleaned $(\mathrm{HCl} 5 \%)$ and rinsed thoroughly (Milli-Q water) before use in the field. In the field, and just before the seeding, the evapocondensed dust was mixed with $2 \mathrm{~L}$ of ultra-pure water (wet deposition experiment: DUNE-P), and the non-processed dust was mixed with $2 \mathrm{~L}$ of seawater (dry deposition experiment: DUNE-Q) (Fig. 12). Overall, the time required to prepare the dust-solution and to seed the three mecocosms was $40 \mathrm{~min}$.

\subsection{Sampling the water column}

The sampling session took place every morning at the same time. The entire operation took $2.5 \mathrm{~h}$ (including spiking and in situ incubation for bottles dedicated to $\mathrm{N}_{2}$ fixation and to primary production measurements). Sampling was also performed every two days outside of the mesocosms. The entire sequence for both experiments is detailed in Table S1 (supplementary info). The first sampling session took place the day before the seeding in order to determine the initial conditions of the experiment. Zooplankton sampling was performed with a WP2 plankton net ( $200 \mu \mathrm{m}$ mesh size) outside the mesocosm at the beginning of the experiment (to avoid any contamination from the device which structure is totally metallic) and inside the mesocosm at the end of the experiment. The sampling was done between $-12 \mathrm{~m}$ and the surface.

The sampling of the exported material was performed by means of small sediment traps $(500-\mathrm{mL}$ high density polyethylene bottles) screwed to the base of the mesocosms

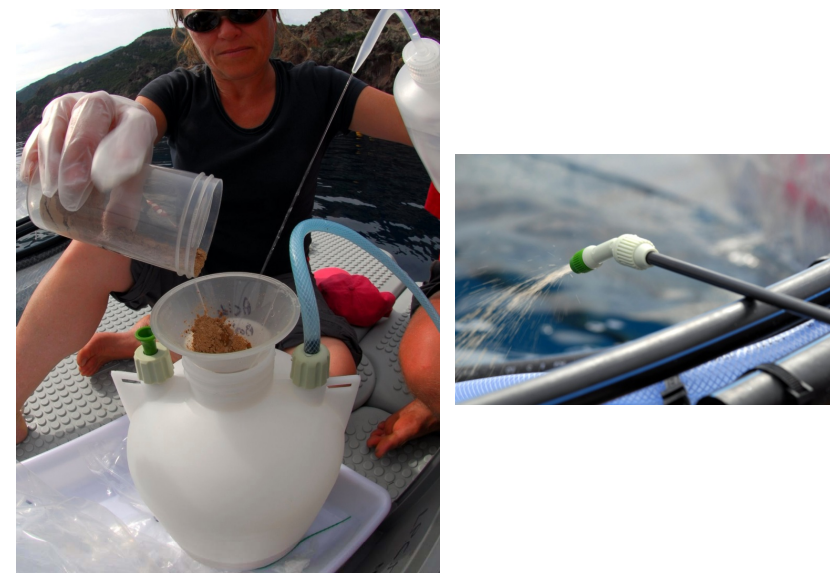

Fig. 12. The different steps of the seeding: (a) on-site preparation of the dust solution in ultra-pure water; (b) spraying the dust solution above the surface water of the mesocosm. The mixture is gently pushed through the hose via a manually operated piston pump (photo: David Luquet, OOV).

and changed every 2 days by divers. Each sample thus represented the amount of material that was exported below $15 \mathrm{~m}$ over a $48 \mathrm{~h}$ period. When the traps were replaced by the diver, the small opening at the base of the bag (diameter $=3.5 \mathrm{~cm}$ ) was left open less than one minute: this could have lead to an exchange of at most a volume of only a few hundred milliliters and the amount of material that could have been lost during the operation was negligible.

\subsection{End of the experiment}

At the end of the first experiment, the bottom cones were unscrewed by divers, leaving the base of the mesocosms open. Thanks to lift bags installed at the base of the bags, the main cylinder could be completely lifted to the surface. This resulted in the entire volume of water trapped inside emptying out of the cylinder, while the top of the mesocosms remained attached to the holding structure. The bags were then ballasted to fill them again, and $24 \mathrm{~h}$ after this operation, the bottom cones were reattached underwater by divers. To eliminate any possibility of a memory effect between DUNE-P and DUNE-Q, the groups of seeded mesocosms were alternated.

\section{Testing the suitability of the approach}

Reproducibility of chemical and biological parameters was tested for initial conditions between samples collected in the three CONTROL-Meso, three DUST-Meso and OUTSIDE. The variation coefficients $(\mathrm{CV}, \%)$ obtained for those seven independent data sets (for all the variables presented below) ranged from $7 \%$ to $33 \%$ for the P-experiment and from 5\% to $33 \%$ for the Q-experiment. The maximum CVs, observed for 
DIP, chlorophyll- $a$ concentration and $\mathrm{N}_{2}$ fixation rate, were explained by the fact that, for these parameters, values were often close to the detection limit. This comparison of the initial conditions indicates that the chemical and biological characteristics of the waters in each of the six mesocosms and OUTSIDE were not significantly different from each other at the beginning of the experiments.

Data obtained during the experiment were submitted for statistical analyses to (1) compare the results obtained in mesocosms that received the same treatment and (2) compare the results obtained in the CONTROL-Meso with the OUTSIDE; in this case, temperature data were also considered. The parameters measured are presented below.

\subsection{Measured parameters}

\section{Stocks}

Bacteria abundance was determined using flow cytometry with a FACSCalibur (BD) as described in Obernosterer et al. (2005) (BA1) and by microscopy of dapi stained cells (BA2). Dissolved iron concentrations (DFe) were measured by flow injection analysis with online preconcentration and chemiluminescence detection, exactly following the same protocol, instrumentation and analytical parameters described in Bonnet and Guieu (2006). Phytoplankton biomass was determined by HPLC (chemotaxonomic pigments were used to assess the contribution of the different algal groups) in two size classes $(<3 \mu \mathrm{m}$ and $>3 \mu \mathrm{m})$. Concentrations of chlorophyll- $a(\mathrm{Chl}-a)$ were determined by fluorimetry "Trilogy Laboratory Fluoromete" - Turner Designs) after extraction in acetone. Dissolved inorganic phosphorus concentrations (DIP) were measured through spectrophotometry using a one meter long waveguide capillary cell (LWCC) (Zhang and Chi, 2002).

\section{Fluxes}

Concentrations of $\mathrm{N}$ and $\mathrm{C}$ in particulate matter, as well as ${ }^{15} \mathrm{~N}$-enrichment in PON and ${ }^{13} \mathrm{C}$-enrichments in POC, were quantified with a mass spectrometer (Delta plus, ThermoFisher Scientific, Bremen, Germany) coupled with a $\mathrm{C} / \mathrm{N}$ analyzer (Flash EA, ThermoFisher Scientific) via a type IIIinterface. $\mathrm{N}_{2}$ fixation rates $\left(\mathrm{N}_{2}\right.$ fix) were calculated by isotope mass balanced as described by Montoya et al. (1996) in parallel with primary production (PP). Bacterial respiration rates were measured in triplicate using 24-h dark incubations of $0.8 \mu \mathrm{m}$-filtered seawater in $60 \mathrm{ml}$ BOD bottles. The respiration rate was calculated as the difference between initial and final concentrations of dissolved oxygen. The concentration of dissolved oxygen was determined spectrophotochemically at a wavelength of $460 \mathrm{~nm}$ using the Winkler standard protocol (Labasque et al., 2004). The sediment traps were preserved after collection with a solution of $2 \%$ buffered formaldehyde in filtered seawater. After treatment of samples (using exactly the same protocol as described in Ternon et al., 2010), the mass fluxes (dry weight of material collected in sediment trap) were obtained by weighing the freeze-dried sample five times.

\subsection{Reproducibility among the three mesocosms receiving the same treatment}

Our strategy was to conduct the seeding experiments in large mesocosms that represented large bodies of water $\left(52 \mathrm{~m}^{3}\right)$. The consequences of atmospheric deposition have never been investigated using such an approach, in particular an approach concerning the aspect of cleanliness required for trace metal and low level nutrient studies. In order to have the maximum robustness for the data obtained, the same dust addition was reproduced in three different mesocosms, and a control was also performed in triplicates. To evaluate the reproducibility of the data obtained from mesocosms receiving the same treatment, the coefficient of variation $(\mathrm{CV}, \%)$ of each measured parameter was calculated for every sampling time and at every sampling depth (Fig. 13).

As shown in Fig. 13, bacterial abundance (measured using two different techniques, see Sect. 6.1), dissolved iron, phytoplankton biomass $>3 \mu \mathrm{m}$ and primary productivity were the most reproducible parameters among the two groups of three mesocosms, and had the lowest CV average $(\leq 20 \%)$. A range of $10-30 \%$ difference between measurements at the same depth and time in the two groups of three mesocosms was observed for Chl-a, DIP and phytoplankton biomass $<3 \mu \mathrm{m}$, and for $\mathrm{N}_{2}$ fix in the group of CONTROLmesocosms. Nitrogen fixation was not reproducible in the group of DUST-mesocosms. In fact, for that parameter, a heterogeneous response of the diazotroph activity was observed, and this discrepancy was attributed to a heterogeneous spatial distribution of those organisms (Ridame et al., 2009, 2010). The high CV in between the three mesocosms receiving the same treatment, thus, does not seem to reflect a technical issue, but was rather due to small scale, high spatial variability, as has already been reported for these organisms from in situ measurements (Biegala and Raimbault, 2008).

With regard to the material collected in the traps, the difference between the three mesocosms receiving the same treatment was the highest during the $P$ experiment, with a difference of at least $30 \%$ of the mass collected in the three traps and an average difference of $65 \%$ in the CONTROL. The difference between traps for the CONTROLS of the Q experiment was also high, with an average of $45 \%$ difference for the three traps. CVs were lower for the three traps in the DUST-mesocosms (28-35\%). This discrepancy could have come first from the design of the trap itself, as the shape of the bottom allowed a small, flat rim close to the screw thread where some exported material did accumulate during the experiment and could not reach the trap. Further, although visual inspection of the inside of both the vertical walls and the cone of the mesocosms at the end of the experiment did 


\begin{tabular}{lccc} 
& & $\begin{array}{c}\text { P experiment } \\
\mathrm{n}=\end{array}$ & $\begin{array}{c}\text { e experiment } \\
\mathrm{n}=\end{array}$ \\
\hline \multirow{2}{*}{ BA1 } & CONTROL & 3 & 4 \\
& DUST & 4 & 4 \\
\hline \multirow{2}{*}{ BA2 } & CONTROL & 12 & - \\
& DUST & 12 & - \\
\hline \multirow{2}{*}{ DFe } & CONTROL & 23 & 27 \\
& DUST & 24 & 27 \\
\hline \multirow{2}{*}{ PP } & CONTROL & 10 & 13 \\
& DUST & 10 & 12 \\
\hline \multirow{2}{*}{ Chla } & CONTROL & 21 & 25 \\
& DUST & 21 & 24 \\
\hline \multirow{2}{*}{ DIP } & CONTROL & 24 & 27 \\
& DUST & 24 & 27 \\
\hline \multirow{2}{*}{ Biomass $<3 \mu \mathrm{m}$} & CONTROL & - & 6 \\
\multirow{2}{*}{ Biomass $>3 \mu \mathrm{mm}$} & DUST & - & 7 \\
\hline \multirow{2}{*}{ Mass flux } & CONTROL & - & 7 \\
& DUST & - & 7 \\
\hline \multirow{2}{*}{ N2 Fix. } & CONTROL & 4 & 4 \\
& DUST & 4 & 4 \\
\hline \multirow{3}{*}{ CONTROL } & 10 & 13 \\
& DUST & 10 & 12 \\
\hline
\end{tabular}

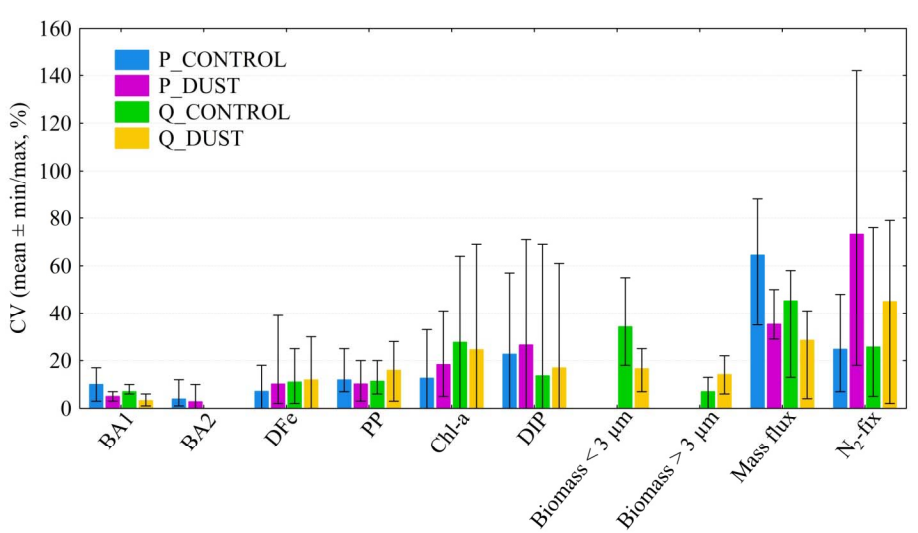

Fig. 13. Mean coefficient variation along with minimum and maximum values obtained for the measured parameters: mean values were calculated for samples collected at the same depth and time in the three mesocosms. The variation coefficients $(\mathrm{CV}$, in \%) derived from these calculations $(\mathrm{CV}=\mathrm{STDEV} \times 100 /$ mean) were then averaged for the duration of the experiment. The number " $n$ " of times, three independent measurements from each group of mesocosms were considered in the calculation is reported for each experiment in the table ("BA1": bacteria abundance from cytometry; "BA2": bacteria abundance as determined by microscopy after dapi stained cells; "DFe": dissolved iron; "Biomass $<3 \mu \mathrm{m}$ " and "Biomass $>3 \mu \mathrm{m}$ ": Phytoplankton biomass in two size classes; "PP": primary production rates; "Chl$a$ ": chlorophyll- $a$ concentration; "DIP": dissolved inorganic phosphorus; "Mass flux": dry weight of material collected in sediment trap; " $\mathrm{N}_{2}$ fix": nitrogen fixation rates).

not allow establishing a significant loss by particle retention, some particulate material could have stuck on the walls. An iron budget during the DUNE-1-P and DUNE-1-Q showed that only a maximum of $60 \%$ of the iron stock lost from the mesocosms after the fertilization (estimated after 48, 120 and $168 \mathrm{~h}$ ) was recovered within the traps (Wagener et al., 2010). This supports the idea that the trap design could have led to uncertainties in, and underestimates of, the amount of exported material. Nevertheless sediment traps data were very useful for quantifying the particulate transfer and for tracing the lithogenic flux, in particular because the dust introduced in the DUST-mesocosms was extremely well-characterized. The sediment traps dataset is fully discussed in (Desboeufs et al., 2010).

Taking into account the design of the experiment and the field conditions, the reproducibility obtained from three mesocosms that received the same treatment was very good, except for $\mathrm{N}_{2}$ fixation. In fact, each bag was filled with $52 \mathrm{~m}^{3}$, and one cannot discard some natural, small-scale spatial variability between the different enclosed water bodies, but this could have been a minor effect as the initial conditions of measured stocks and fluxes in the six bags and OUTSIDE compared very well. With regard to the field conditions, bags were installed in situ where the swell, the influence of surrounding current, and the light could not be exactly the same in the six large mesocosms. However, we have evidence for light, a critical parameter for biology and chemistry, from pigments measurements (C. Brunet), that the photoprotective pigment ratio (the so called xanthophyll cycle) measured at $5 \mathrm{~m}$ depth was similar between the triplicates, revealing a non-significant difference of light received by cells at this depth.

The evolution, as a function of time and depth, of both the CONTROL and the DUST mesocosms was well constrained by the numbers obtained. In fact, those CVs are close to the precision of the measurements themselves (for example, replicate measurements of DFe concentrations on a same sample analyzed three times have a CV of ca. 3 to $8 \%$; Wagener et al., 2010.).

The numbers obtained in three bags receiving the same treatment were very much comparable for most of the parameters measured, indicating that the biological and chemical response did not differ from one bag to another. Also, there was no evidence from the parameters measured that different assemblages had develop in bags receiving the same treatment (see for ex. Laghdass et al. 2010 on the evolution of the composition of the heterotrophic bacterial community). The results obtained in three bags receiving the same treatment can thus be considered as triplicates.

\subsection{Comparison of parameters measured inside CONTROL-Meso and OUTSIDE}

One major issue of the experiments presented in this paper concerns the representativeness of in situ biogeochemical conditions of the water body trapped in the mesocosms. To address this question, we performed $t$-tests between CONTROL-Meso and OUTSIDE for each measured parameter and at every sampling depth and time. The prerequisite for this statistical analysis was the simultaneous 


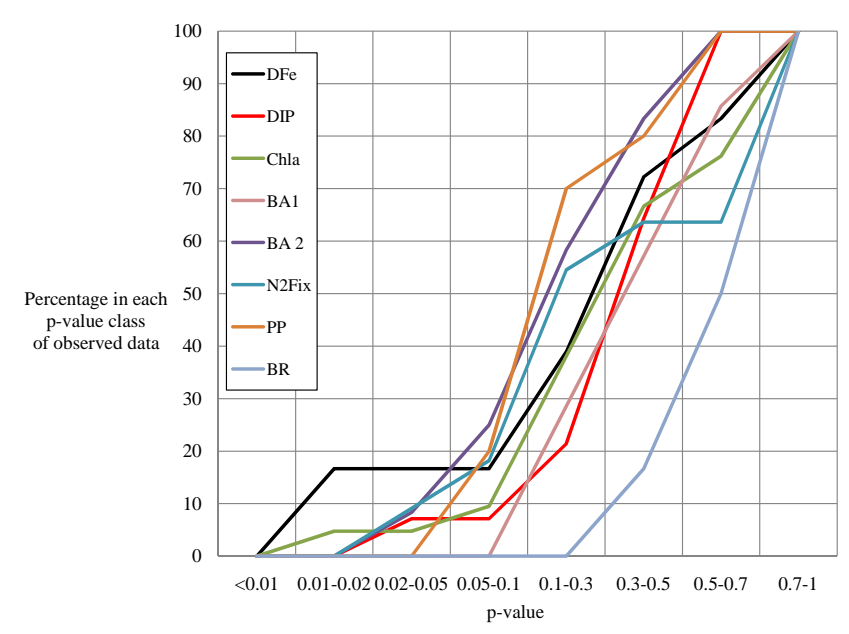

Fig. 14. The cumulative (in \%) distribution function of the $p$-values computed from $t$-test comparing CONTROL and OUTSIDE data (labels: same as in Fig. 13 and "BR": bacteria respiration).

measurement between CONTROL-meso and OUTSIDE. Thus, the number of performed analyses varies among parameters depending on the frequency of sampling (Table 3) and on exceptional events such as the loss or contamination of a sample.

The full $p$-value data set computed from $t$-tests is reported in supplementary information (Table S2), and only a synthesis of those results is presented here. The computed $p$-values represent the probability of error involved in accepting the hypothesis of a difference and so, high $p$-values correspond to non-significant differences between CONTROL-meso and OUTSIDE. Figure 14 represents, for all parameters, the cumulative distribution function of the computed $p$-values: if the difference between CONTROL and OUTSIDE is large, then, a large fraction of the computed analyses will give small $p$-values. For only DFe, more than $5 \%$ of all the $t$ tests performed indicated that data between CONTROL and OUTSIDE had a high probability ( $>0.98$ ) of being different. For DFe, this number was $17 \%$.

Seawater temperature was also continuously recorded inside and outside one of the "CONTROL-meso" for the duration of both experiments. Temperature sensors equipped with autonomous data loger (Micrel S2T) were placed at $0.1 \mathrm{~m}$, $5 \mathrm{~m}$ and $10 \mathrm{~m}$. These small sensors $(10 \mathrm{~cm}$ in length $\times 2 \mathrm{~cm}$ in diameter) were enclosed in a PVC cover. In addition, CTD profiles were performed for the duration of the experiment at different sites around the mesocosm platforms, in particular in open water "OUTSIDE" sampling site. The comparison (Fig. 15) shows a strong agreement between temperature sensor measurements inside and outside the bags and indicates that CTD data compared well with the temperature recorded inside the mesocosm. These data indicate that the temperature conditions inside the mesocosm nicely reflected the evolution of the in situ water temperature. These conclusions (a)

DUNE-1_P_Temperature

(b)
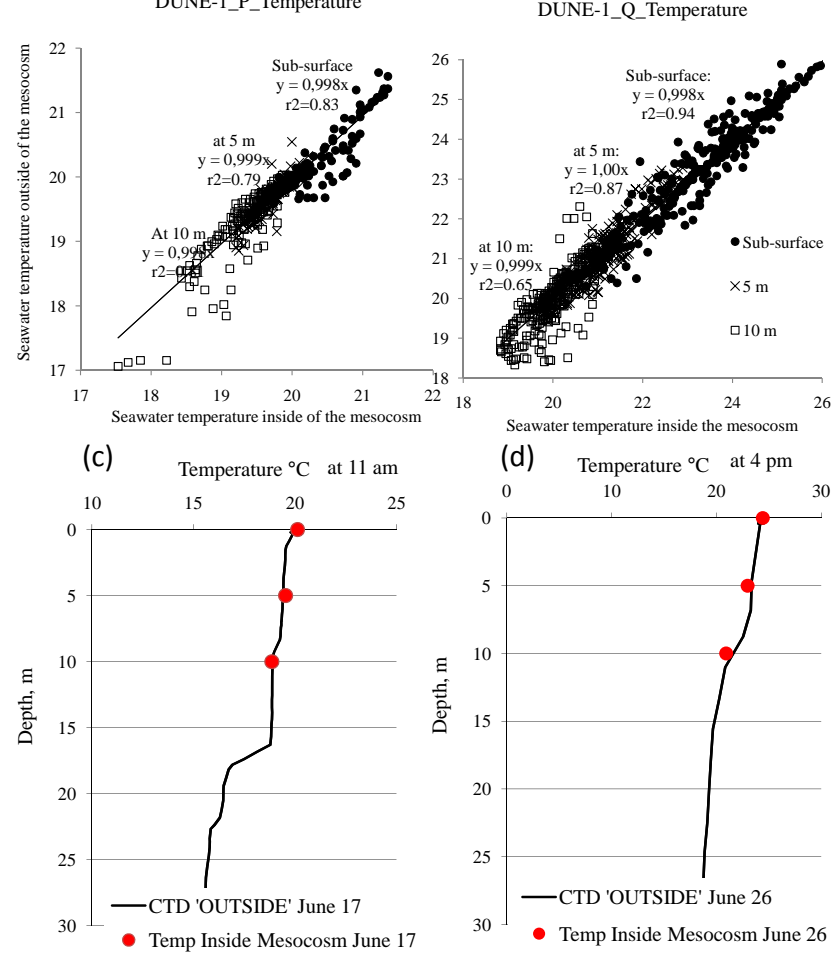

(d) Temperature ${ }^{\circ} \mathrm{C}$ at $4 \mathrm{pm}$

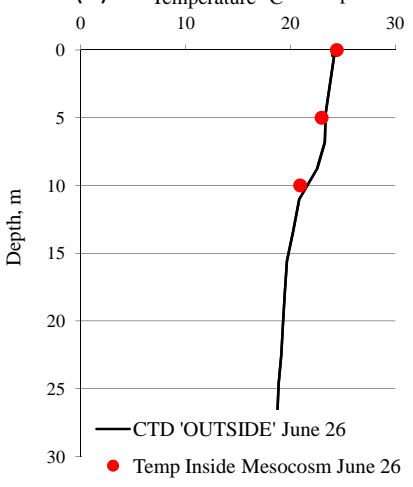

Fig. 15. Comparison of the temperatures $\left({ }^{\circ} \mathrm{C}\right)$ measured continuously ( $1 \mathrm{data} / \mathrm{h})$ inside and outside one of the six mesocosms at three fixed depths during the DUNE1-P experiment (a) and the DUNE1$\mathrm{Q}$ experiment (b). In addition, a comparison between the temperature inside the bags at $0.1,5$ and $10 \mathrm{~m}$ along with the temperature data acquired by CTD at the same time in open waters at the "OUTSIDE" site (c) on 17 June at 11:00 a.m. and (d) on 26 June at 04:00 p.m.

allowed us to construct the temperature evolution during both experiments (Fig. 11).

Statistical analyses performed gave strong evidence of the representativeness of the water trapped inside the mesocosms. This confirms the suitability of the applied methodology and indicates that the presence of the bag did not modify the natural biogeochemical conditions, and that there was no chemical contamination.

\section{Conclusions}

To summarize, (1) the dust aerosol source soil collection, fine particle mechanical production and laboratory aging using a simulated cloud water was an appropriate strategy to obtain the necessary amount of representative dust to perform seeding experiments in large mesocosms to simulate dry or wet atmospheric deposition of desert dust, (2) the experimental platform gave a very satisfactory performance for the multidisciplinary studies undertaken during the DUNE-1 campaign; in particular, we have shown that the variation 
Table 3. Sampling planning. The corresponding sampling time/day are reported in Table S1 (supp. info).

\begin{tabular}{|c|c|c|c|c|c|c|c|c|c|c|c|c|c|c|c|c|c|c|c|c|c|c|c|}
\hline \multicolumn{11}{|c|}{ P_experiment } & \multicolumn{13}{|c|}{ Q_Experiment } \\
\hline & & depth & $\mathrm{DFe}$ & DIP & Chl- $a$ & BA1 & BA2 & N2Fix & PP & BR & & & depth & $\mathrm{DFe}$ & DIP & Chl- $a$ & BA1 & BA2 & N2Fix & $\mathrm{PP}$ & $\mathrm{BR}$ & $b<3 \mu \mathrm{m}$ & $b>3 \mu \mathrm{m}$ \\
\hline & & 0 & & $\mathrm{x}$ & $\mathrm{x}$ & & & $\mathrm{x}$ & $\mathrm{x}$ & & & & 0 & $\mathrm{x}$ & $\mathrm{x}$ & $\mathrm{x}$ & $\mathrm{x}$ & & $\mathrm{x}$ & $\mathrm{x}$ & & & \\
\hline P1 & OUTSIDE & 5 & & $\mathrm{x}$ & $\mathrm{x}$ & & $\mathrm{x}$ & $\mathrm{x}$ & $\mathrm{x}$ & & Q1 & OUTSIDE & 5 & $\mathrm{x}$ & $\mathrm{x}$ & $\mathrm{x}$ & $\mathrm{x}$ & $\mathrm{x}$ & $\mathrm{x}$ & $\mathrm{x}$ & $\mathrm{x}$ & $\mathrm{x}$ & $\mathrm{x}$ \\
\hline & & 10 & & $\mathrm{x}$ & & $\mathrm{x}$ & & & & & & & 10 & $\mathrm{x}$ & $\mathrm{x}$ & $\mathrm{x}$ & $\mathrm{x}$ & & & & & & \\
\hline & & 0 & $\mathrm{x}$ & $\mathrm{x}$ & $\mathrm{x}$ & $\mathrm{x}$ & & $\mathrm{x}$ & $\mathrm{x}$ & & & & 0 & $\mathrm{x}$ & $\mathrm{x}$ & $\mathrm{x}$ & $\mathrm{x}$ & & $\mathrm{x}$ & $\mathrm{x}$ & & & \\
\hline P1 & CONTROL & 5 & $\mathrm{x}$ & $\mathrm{x}$ & $\mathrm{x}$ & $\mathrm{x}$ & $\mathrm{x}$ & $\mathrm{x}$ & $\mathrm{x}$ & $\mathrm{x}$ & Q1 & CONTROL & 5 & $\mathrm{x}$ & $\mathrm{x}$ & $\mathrm{x}$ & $\mathrm{x}$ & $\mathrm{x}$ & $\mathrm{x}$ & $\mathrm{x}$ & $\mathrm{x}$ & $\mathrm{x}$ & $\mathrm{x}$ \\
\hline & & 10 & $\mathrm{x}$ & $\mathrm{x}$ & $\mathrm{x}$ & $\mathrm{x}$ & & & & & & & 10 & $\mathrm{x}$ & $\mathrm{x}$ & $\mathrm{x}$ & $\mathrm{x}$ & & & & & & \\
\hline & & 0 & $\mathrm{x}$ & $\mathrm{x}$ & $\mathrm{x}$ & $\mathrm{x}$ & & $\mathrm{x}$ & $\mathrm{x}$ & & & & 0 & $\mathrm{x}$ & $\mathrm{x}$ & $\mathrm{x}$ & $\mathrm{x}$ & & $\mathrm{x}$ & $\mathrm{x}$ & & & \\
\hline P1 & DUST & 5 & $\mathrm{x}$ & $\mathrm{x}$ & $\mathrm{x}$ & $\mathrm{x}$ & $\mathrm{x}$ & $\mathrm{x}$ & $\mathrm{x}$ & $\mathrm{x}$ & Q1 & DUST & 5 & $\mathrm{x}$ & $\mathrm{x}$ & $\mathrm{x}$ & $\mathrm{x}$ & $\mathrm{x}$ & $\mathrm{x}$ & $\mathrm{x}$ & $\mathrm{x}$ & $\mathrm{x}$ & $\mathrm{x}$ \\
\hline & & 10 & $\mathrm{x}$ & $\mathrm{x}$ & $\mathrm{x}$ & $\mathrm{x}$ & & & & & & & 10 & $\mathrm{x}$ & $\mathrm{x}$ & $\mathrm{x}$ & $\mathrm{x}$ & & & & & & \\
\hline & & 0 & $\mathrm{x}$ & $\mathrm{x}$ & $\mathrm{x}$ & & & & & & & & 0 & $\mathrm{x}$ & $\mathrm{x}$ & $\mathrm{x}$ & & & & & & & \\
\hline P2 & CONTROL & 5 & $\mathrm{x}$ & $\mathrm{x}$ & $\mathrm{x}$ & & & & & & Q2 & CONTROL & 5 & $\mathrm{x}$ & $\mathrm{x}$ & $\mathrm{x}$ & & & & & & & \\
\hline & & 10 & $\mathrm{x}$ & $\mathrm{x}$ & $\mathrm{x}$ & & & & & & & & 10 & $\mathrm{x}$ & $\mathrm{x}$ & $\mathrm{x}$ & & & & & & & \\
\hline & & 0 & $\mathrm{x}$ & $\mathrm{x}$ & $\mathrm{x}$ & & & & & & & & 0 & $\mathrm{x}$ & $\mathrm{x}$ & $\mathrm{x}$ & & & & & & & \\
\hline P2 & DUST & 5 & $\mathrm{x}$ & $\mathrm{x}$ & $\mathrm{x}$ & & & & & & Q2 & DUST & 5 & $\mathrm{x}$ & $\mathrm{x}$ & $\mathrm{x}$ & & & & & & & \\
\hline & & 10 & $\mathrm{x}$ & $\mathrm{x}$ & $\mathrm{x}$ & & & & & & & & 10 & $\mathrm{x}$ & $\mathrm{x}$ & $\mathrm{x}$ & & & & & & & \\
\hline & & 0 & $\mathrm{x}$ & $\mathrm{x}$ & $\mathrm{x}$ & $\mathrm{x}$ & & $\mathrm{x}$ & $\mathrm{x}$ & & & & 0 & $\mathrm{x}$ & $\mathrm{x}$ & $\mathrm{x}$ & $\mathrm{x}$ & & $\mathrm{x}$ & $\mathrm{x}$ & & & \\
\hline P3 & CONTROL & 5 & $\mathrm{x}$ & $\mathrm{x}$ & $\mathrm{x}$ & $\mathrm{x}$ & & $\mathrm{x}$ & $\mathrm{x}$ & & Q3 & CONTROL & 5 & $\mathrm{x}$ & $\mathrm{x}$ & $\mathrm{x}$ & $\mathrm{x}$ & & $\mathrm{x}$ & $\mathrm{x}$ & & $\mathrm{x}$ & $\mathrm{x}$ \\
\hline & & 10 & $\mathrm{x}$ & $\mathrm{x}$ & $\mathrm{x}$ & $\mathrm{x}$ & & & & & & & 10 & $\mathrm{x}$ & $\mathrm{x}$ & $\mathrm{x}$ & $\mathrm{x}$ & & & & & & \\
\hline & & 0 & $\mathrm{x}$ & $\mathrm{x}$ & $\mathrm{x}$ & $\mathrm{x}$ & & $\mathrm{x}$ & $\mathrm{x}$ & & & & 0 & $\mathrm{x}$ & $\mathrm{x}$ & $\mathrm{x}$ & $\mathrm{x}$ & & $\mathrm{x}$ & $\mathrm{x}$ & & & \\
\hline P3 & DUST & 5 & $\mathrm{x}$ & $\mathrm{x}$ & $\mathrm{x}$ & $\mathrm{x}$ & & $\mathrm{x}$ & $\mathrm{x}$ & & Q3 & DUST & 5 & $\mathrm{x}$ & $\mathrm{x}$ & $\mathrm{x}$ & $\mathrm{x}$ & & $\mathrm{x}$ & $\mathrm{x}$ & & $\mathrm{x}$ & $\mathrm{x}$ \\
\hline & & 10 & $\mathrm{x}$ & $\mathrm{x}$ & $\mathrm{x}$ & $\mathrm{x}$ & & & & & & & 10 & $\mathrm{x}$ & $\mathrm{x}$ & $\mathrm{x}$ & $\mathrm{x}$ & & & & & & \\
\hline & & 0 & $\mathrm{x}$ & $x$ & $\mathrm{x}$ & $\mathrm{x}$ & & & & & & & 0 & $\mathrm{x}$ & $\mathrm{x}$ & $\mathrm{x}$ & $\mathrm{x}$ & & $\mathrm{x}$ & $\mathrm{x}$ & & & \\
\hline P4 & OUTSIDE & 5 & $\mathrm{x}$ & $\mathrm{x}$ & $\mathrm{x}$ & $\mathrm{x}$ & $\mathrm{x}$ & & & $\mathrm{x}$ & Q4 & OUTSIDE & 5 & $\mathrm{x}$ & $\mathrm{x}$ & $\mathrm{x}$ & $\mathrm{x}$ & $\mathrm{x}$ & $\mathrm{x}$ & $\mathrm{x}$ & $\mathrm{x}$ & $\mathrm{x}$ & $\mathrm{x}$ \\
\hline & & 10 & $\mathrm{x}$ & $\mathrm{x}$ & $\mathrm{x}$ & $\mathrm{x}$ & & & & & & & 10 & $\mathrm{x}$ & $\mathrm{x}$ & $\mathrm{x}$ & $\mathrm{x}$ & & & & & & \\
\hline & & 0 & $\mathrm{x}$ & $\mathrm{x}$ & $\mathrm{x}$ & $\mathrm{x}$ & & $\mathrm{x}$ & $\mathrm{x}$ & & & & 0 & $\mathrm{x}$ & $\mathrm{x}$ & $\mathrm{x}$ & $\mathrm{x}$ & & $\mathrm{x}$ & $\mathrm{x}$ & & & \\
\hline $\mathrm{P} 4$ & CONTROL & 5 & $\mathrm{x}$ & $\mathrm{x}$ & $\mathrm{x}$ & $\mathrm{x}$ & $\mathrm{x}$ & $\mathrm{x}$ & $\mathrm{x}$ & $\mathrm{x}$ & Q4 & CONTROL & 5 & $\mathrm{x}$ & $\mathrm{x}$ & $x$ & $\mathrm{x}$ & $\mathrm{x}$ & $\mathrm{x}$ & $\mathrm{x}$ & $\mathrm{x}$ & $\mathrm{x}$ & $\mathrm{x}$ \\
\hline & & 10 & $\mathrm{x}$ & $\mathrm{x}$ & $\mathrm{x}$ & $\mathrm{x}$ & & & & & & & 10 & $\mathrm{x}$ & $\mathrm{x}$ & $\mathrm{x}$ & $\mathrm{x}$ & & & & & & \\
\hline & & 0 & $\mathrm{x}$ & $\mathrm{x}$ & $\mathrm{x}$ & $\mathrm{x}$ & & $\mathrm{x}$ & $\mathrm{x}$ & & & & 0 & $\mathrm{x}$ & $\mathrm{x}$ & $\mathrm{x}$ & $\mathrm{x}$ & & $\mathrm{x}$ & $\mathrm{x}$ & & & \\
\hline $\mathrm{P} 4$ & DUST & 5 & $\mathrm{x}$ & $\mathrm{x}$ & $\mathrm{x}$ & $\mathrm{x}$ & $\mathrm{x}$ & $\mathrm{x}$ & $\mathrm{x}$ & $\mathrm{x}$ & Q4 & DUST & 5 & $\mathrm{x}$ & $\mathrm{x}$ & $x$ & $\mathrm{x}$ & $\mathrm{x}$ & $\mathrm{x}$ & $\mathrm{x}$ & $\mathrm{x}$ & $\mathrm{x}$ & $\mathrm{x}$ \\
\hline & & 10 & $\mathrm{x}$ & $\mathrm{x}$ & $\mathrm{x}$ & $\mathrm{x}$ & & & & & & & 10 & $\mathrm{x}$ & $\mathrm{x}$ & $\mathrm{x}$ & $\mathrm{x}$ & & & & & & \\
\hline & & 0 & $\mathrm{x}$ & $\mathrm{x}$ & $\mathrm{x}$ & $\mathrm{x}$ & & $\mathrm{x}$ & $\mathrm{x}$ & & & & 0 & $\mathrm{x}$ & $\mathrm{x}$ & $\mathrm{x}$ & $\mathrm{x}$ & & $\mathrm{x}$ & $\mathrm{x}$ & & $\mathrm{x}$ & $\mathrm{x}$ \\
\hline P5 & CONTROL & 5 & $\mathrm{x}$ & $\mathrm{x}$ & $\mathrm{x}$ & $\mathrm{x}$ & & $\mathrm{x}$ & $\mathrm{x}$ & & Q5 & CONTROL & 5 & $\mathrm{x}$ & $\mathrm{x}$ & $\mathrm{x}$ & $\mathrm{x}$ & & $\mathrm{x}$ & $\mathrm{x}$ & & & \\
\hline & & 10 & $\mathrm{x}$ & $\mathrm{x}$ & $\mathrm{x}$ & $\mathrm{x}$ & & & & & & & 10 & $\mathrm{x}$ & $\mathrm{x}$ & $\mathrm{x}$ & $\mathrm{x}$ & & & & & & \\
\hline & & 0 & $\mathrm{x}$ & $\mathrm{x}$ & $\mathrm{x}$ & $\mathrm{x}$ & & $\mathrm{x}$ & $\mathrm{x}$ & & & & 0 & $\mathrm{x}$ & $\mathrm{x}$ & $\mathrm{x}$ & $\mathrm{x}$ & & $\mathrm{x}$ & $\mathrm{x}$ & & $\mathrm{x}$ & $\mathrm{x}$ \\
\hline P5 & DUST & 5 & $\mathrm{x}$ & $\mathrm{x}$ & $\mathrm{x}$ & $x$ & & $\mathrm{x}$ & $\mathrm{x}$ & & Q5 & DUST & 5 & $\mathrm{x}$ & $\mathrm{x}$ & $x$ & $\mathrm{x}$ & & $\mathrm{x}$ & $\mathrm{x}$ & & & \\
\hline & & 10 & $\mathrm{x}$ & $\mathrm{x}$ & $\mathrm{x}$ & $\mathrm{x}$ & & & & & & & 10 & $\mathrm{x}$ & $\mathrm{x}$ & $\mathrm{x}$ & $\mathrm{x}$ & & & & & & \\
\hline & & 0 & $\mathrm{x}$ & $\mathrm{x}$ & $\mathrm{x}$ & $\mathrm{x}$ & & & & & & & 0 & & & & & & & & & & \\
\hline P6 & OUTSIDE & 5 & $x$ & $\mathrm{x}$ & $\mathrm{x}$ & $\mathrm{x}$ & $\mathrm{x}$ & & & $\mathrm{x}$ & Q6 & OUTSIDE & 5 & & & & & & & & & $\mathrm{x}$ & $x$ \\
\hline & & 10 & $\mathrm{x}$ & $\mathrm{x}$ & $\mathrm{x}$ & $\mathrm{x}$ & & & & & & & 10 & & & & & & & & & & \\
\hline & & 0 & $\mathrm{x}$ & $\mathrm{x}$ & $\mathrm{x}$ & $\mathrm{x}$ & & & & & & & 0 & $\mathrm{x}$ & $\mathrm{x}$ & $\mathrm{x}$ & $\mathrm{x}$ & & & & & & \\
\hline P6 & CONTROL & 5 & $\mathrm{x}$ & $\mathrm{x}$ & $\mathrm{x}$ & $\mathrm{x}$ & $\mathrm{x}$ & & & $\mathrm{x}$ & Q6 & CONTROL & 5 & $\mathrm{x}$ & $\mathrm{x}$ & $\mathrm{x}$ & $\mathrm{x}$ & & & & & $\mathrm{x}$ & $\mathrm{x}$ \\
\hline & & 10 & $\mathrm{x}$ & $\mathrm{x}$ & $\mathrm{x}$ & $\mathrm{x}$ & & & & & & & 10 & $\mathrm{x}$ & $\mathrm{x}$ & $\mathrm{x}$ & $\mathrm{x}$ & & & & & & \\
\hline & & 0 & $\mathrm{x}$ & $\mathrm{x}$ & $\mathrm{x}$ & $\mathrm{x}$ & & & & & & & 0 & $\mathrm{x}$ & $\mathrm{x}$ & $\mathrm{x}$ & $\mathrm{x}$ & & & & & & \\
\hline P6 & DUST & 5 & $x$ & $\mathrm{x}$ & $\mathrm{x}$ & $\mathrm{x}$ & $\mathrm{x}$ & & & $x$ & Q6 & DUST & 5 & $\mathrm{x}$ & $\mathrm{x}$ & $x$ & $\mathrm{x}$ & & & & & $\mathrm{x}$ & $x$ \\
\hline & & 10 & $\mathrm{x}$ & $\mathrm{x}$ & $\mathrm{x}$ & $\mathrm{x}$ & & & & & & & 10 & $\mathrm{x}$ & $\mathrm{x}$ & $\mathrm{x}$ & $\mathrm{x}$ & & & & & & \\
\hline & & 0 & $\mathrm{x}$ & $\mathrm{x}$ & $\mathrm{x}$ & $\mathrm{x}$ & & & & & & & 0 & $\mathrm{x}$ & $\mathrm{x}$ & $\mathrm{x}$ & $\mathrm{x}$ & & $\mathrm{x}$ & $\mathrm{x}$ & & & \\
\hline P7 & CONTROL & 5 & $\mathrm{x}$ & $\mathrm{x}$ & $\mathrm{x}$ & $\mathrm{x}$ & & & & & Q7 & OUTSIDE & 5 & $\mathrm{x}$ & $\mathrm{x}$ & $\mathrm{x}$ & $\mathrm{x}$ & $\mathrm{x}$ & $\mathrm{x}$ & $\mathrm{x}$ & $\mathrm{x}$ & $\mathrm{x}$ & $\mathrm{x}$ \\
\hline & & 10 & $\mathrm{x}$ & $\mathrm{x}$ & $\mathrm{x}$ & $\mathrm{x}$ & & & & & & & 10 & $\mathrm{x}$ & $\mathrm{x}$ & $\mathrm{x}$ & $\mathrm{x}$ & & & & & & \\
\hline & & 0 & $\mathrm{x}$ & $\mathrm{x}$ & $\mathrm{x}$ & $\mathrm{x}$ & & & & & & & 0 & $\mathrm{x}$ & $\mathrm{x}$ & $\mathrm{x}$ & $\mathrm{x}$ & & $x$ & $\mathrm{x}$ & & & \\
\hline P7 & DUST & 5 & $\mathrm{x}$ & $\mathrm{x}$ & $\mathrm{x}$ & $\mathrm{x}$ & & & & & Q7 & CONTROL & 5 & $\mathrm{x}$ & $\mathrm{x}$ & $x$ & $x$ & $\mathrm{x}$ & $\mathrm{x}$ & $\mathrm{x}$ & $\mathrm{x}$ & $\mathrm{x}$ & $\mathrm{x}$ \\
\hline & & 10 & $x$ & $\mathrm{x}$ & $\mathrm{x}$ & $\mathrm{x}$ & & & & & & & 10 & $\mathrm{x}$ & $\mathrm{x}$ & $x$ & $\mathrm{x}$ & & & & & & \\
\hline & & 0 & $\mathrm{x}$ & $\mathrm{x}$ & $\mathrm{x}$ & $\mathrm{x}$ & & $\mathrm{x}$ & $\mathrm{x}$ & & & & 0 & $\mathrm{x}$ & $\mathrm{x}$ & $\mathrm{x}$ & $\mathrm{x}$ & & $x$ & $\mathrm{x}$ & & & \\
\hline P8 & OUTSIDE & 5 & $\mathrm{x}$ & $\mathrm{x}$ & $\mathrm{x}$ & $\mathrm{x}$ & $\mathrm{x}$ & $\mathrm{x}$ & $\mathrm{x}$ & $\mathrm{x}$ & Q7 & DUST & 5 & $\mathrm{x}$ & $\mathrm{x}$ & $\mathrm{x}$ & $\mathrm{x}$ & $\mathrm{x}$ & $\mathrm{x}$ & $\mathrm{x}$ & $\mathrm{x}$ & $\mathrm{x}$ & $\mathrm{x}$ \\
\hline & & 10 & $\mathrm{x}$ & $\mathrm{x}$ & $\mathrm{x}$ & $\mathrm{x}$ & & & & & & & 10 & $\mathrm{x}$ & $\mathrm{x}$ & $\mathrm{x}$ & $\mathrm{x}$ & & & & & & \\
\hline & & 0 & $\mathrm{x}$ & $\mathrm{x}$ & $\mathrm{x}$ & $\mathrm{x}$ & & $\mathrm{x}$ & $\mathrm{x}$ & & & & 0 & $\mathrm{x}$ & $\mathrm{x}$ & $x$ & $\mathrm{x}$ & & & & & & \\
\hline P8 & CONTROL & 5 & $\mathrm{x}$ & $\mathrm{x}$ & $\mathrm{x}$ & $\mathrm{x}$ & $\mathrm{x}$ & $\mathrm{x}$ & $\mathrm{x}$ & $\mathrm{x}$ & Q8 & CONTROL & 5 & $\mathrm{x}$ & $\mathrm{x}$ & $\mathrm{x}$ & $\mathrm{x}$ & & & & & & \\
\hline & & 10 & $x$ & $\mathrm{x}$ & $\mathrm{x}$ & $\mathrm{x}$ & & & & & & & 10 & $\mathrm{x}$ & $\mathrm{x}$ & $x$ & $\mathrm{x}$ & & & & & & \\
\hline & & 0 & $\mathrm{x}$ & $\mathrm{x}$ & $\mathrm{x}$ & $\mathrm{x}$ & & $\mathrm{x}$ & $\mathrm{x}$ & & & & 0 & $\mathrm{x}$ & $\mathrm{x}$ & $\mathrm{x}$ & $\mathrm{x}$ & & & & & & \\
\hline P8 & DUST & 5 & $\mathrm{x}$ & $\mathrm{x}$ & $\mathrm{x}$ & $\mathrm{x}$ & $\mathrm{x}$ & $\mathrm{x}$ & $\mathrm{x}$ & $\mathrm{x}$ & Q8 & DUST & 5 & $\mathrm{x}$ & $\mathrm{x}$ & $\mathrm{x}$ & $\mathrm{x}$ & & & & & & \\
\hline & & 10 & $\mathrm{x}$ & $\mathrm{x}$ & $\mathrm{x}$ & $\mathrm{x}$ & & & & & & & 10 & $\mathrm{x}$ & $\mathrm{x}$ & $\mathrm{x}$ & $\mathrm{x}$ & & & & & & \\
\hline & & & & & & & & & & & & & 0 & $\mathrm{x}$ & $\mathrm{x}$ & $\mathrm{x}$ & $\mathrm{x}$ & & $\mathrm{x}$ & $\mathrm{x}$ & & & \\
\hline & & & & & & & & & & & Q9 & OUTSIDE & 5 & $\mathrm{x}$ & $\mathrm{x}$ & $\mathrm{x}$ & $\mathrm{x}$ & $\mathrm{x}$ & $\mathrm{x}$ & $\mathrm{x}$ & $\mathrm{x}$ & & \\
\hline & & & & & & & & & & & & & 10 & $\mathrm{x}$ & $\mathrm{x}$ & $\mathrm{x}$ & $\mathrm{x}$ & & & & & & \\
\hline & & & & & & & & & & & & & 0 & $\mathrm{x}$ & $\mathrm{x}$ & $x$ & $\mathrm{x}$ & & $x$ & $\mathrm{x}$ & & & \\
\hline & & & & & & & & & & & Q9 & CONTROL & 5 & $\mathrm{x}$ & $\mathrm{x}$ & $x$ & $\mathrm{x}$ & $\mathrm{x}$ & $\mathrm{x}$ & $\mathrm{x}$ & $\mathrm{x}$ & & \\
\hline & & & & & & & & & & & & & 10 & $\mathrm{x}$ & $\mathrm{x}$ & $x$ & $\mathrm{x}$ & & & & & & \\
\hline & & & & & & & & & & & & & 0 & $\mathrm{x}$ & $\mathrm{x}$ & $\mathrm{x}$ & $\mathrm{x}$ & & $\mathrm{x}$ & $\mathrm{x}$ & & & \\
\hline & & & & & & & & & & & Q9 & DUST & 5 & $\mathrm{x}$ & $\mathrm{x}$ & $\mathrm{x}$ & $\mathrm{x}$ & $\mathrm{x}$ & $\mathrm{x}$ & $\mathrm{x}$ & $\mathrm{x}$ & & \\
\hline & & & & & & & & & & & & & 10 & $\mathrm{x}$ & $\mathrm{x}$ & $x$ & $x$ & & & & & & \\
\hline
\end{tabular}

between triplicates was low for most of the parameters, that the deployment of the mesocosms did not induce contamination of the enclosed water mass. Nevertheless, some improvements will have to be made regarding the device used to collect the exported material.
The methodology developed in the DUNE project is suitable to quantify and parameterize the impact of atmospheric forcing in a LNLC ecosystem. This type of integrated, in situ approach will allow us to eventually be able to parameterize the main processes involved in the ecosystem function in response to external forcing such as the atmospheric 
input. This will allow a realistic representation in biogeochemical models of the response to atmospheric chemical forcing because such large mesocosms can be considered as 1-D ecosystems.

\section{Supplementary material related to this article is available online at: http://www.biogeosciences.net/7/2765/2010/ bg-7-2765-2010-supplement.pdf.}

Acknowledgements. This work was funded by the ANR DUNE under the contract "ANR-07-BLAN-0126-01". The pilot phase of the DUNE project was funded by BQR University of Paris 6 and National Program INSU-LEFE/CYBER. Field campaign in Tunisia: The Director of IRA Houcine Khatteli is especially acknowledged for making possible our collaboration in the framework of the project DUNE and for providing facilities. We are grateful to Dirk Goossens for first suggesting the collection of soil material for simulating transported dust. Mouldi Kardous and Jean-Louis Rajot are acknowledged for providing information from a former recce in the vicinity of Douz. The authors thank Laure Aimoz for her help in the analysis of the chemical and mineralogical compositions of dust. Field work in Corsica: this field campaign could not have taken place without the logistical support and available facilities of the Parc Naturel Régional de Corse, and the authors wish to warmly thank, in particular, the crew of Scandola at Galéria who made possible the installation of the experimental setup and the everyday transportation of the sampling team to the site. The divers David Luquet, Christian Rouvière and Laurent Gilletta from the Observatoire d'Océanologie de Villefranche are greatly acknowledged for their helpful work in the field. The large number of samples collected everyday would not have been possible without the help of Marine Deschatres. Nathalie Leblond performed the sediment trap treatment, and Philippe Catala performed the cytometry analysis. Marie-Dominique Loÿe-Pilot is thanked for her help in finding the site in Corsica. We thank K. Forbes for editing the manuscript.

Edited by: U. Riebesell

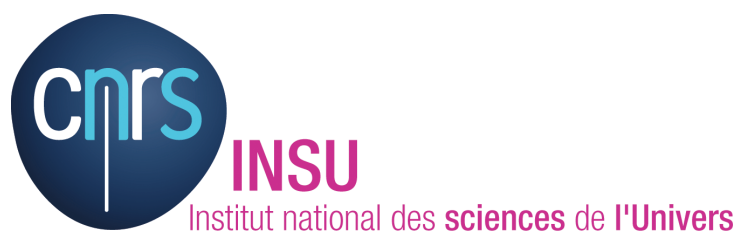

The publication of this article is financed by CNRS-INSU.

\section{References}

Aiuppa, A., Bonfanti, P., and D’Alessandro, W.: Rainwater chemistry at mt. Etna (Italy): Natural and anthropogenic sources of major ions, J. Atmos. Chem., 46, 89-102, 2003.

Alfaro, S. C., Gaudichet, A., Gomes, L., and MAillé, M.: Mineral aerosol production by wind erosion: aerosol particle sizes and binding energies, Geophys. Res. Lett., 25, 991-994, 1998.

Anderson, L. D., Faul, K. L., and Paytan, A.: Phosphorus associations in aerosols: What can they tell us about "P" bioavailability?, Mar. Chem., 120, 44-56, 2010.

Avila, A., Alarcon, M., Castillo, S., Escudero, M., Garcıa Orellana, J., Masque, P., and Querol, X.: Variation of soluble and insoluble calcium in red rains related to dust sources and transport patterns from North Africa to northeastern Spain, J. Geophys. Res., 112, D05210, doi:10.1029/2006JD007153, 2007.

Aymoz, G., Jaffrezo, J.-L., Jacob, V., Colomb, A., and George, Ch.: Evolution of organic and inorganic components of aerosol during a Saharan dust episode observed in the French Alps, Atmos. Chem. Phys., 4, 2499-2512, doi:10.5194/acp-4-2499-2004, 2004.

Baker, A. R., Kelly, S. D., Biswas, K. F., Witt, M., and Jickells, T. D.: Atmospheric deposition of nutrients to the Atlantic Ocean, Geophys. Res. Lett., 30(24), 2296, doi:10.1029/2003GL018518, 2003.

Balestrini, R., Galli, L., and Tartari, G.: Wet and dry atmospheric deposition at prealpine and alpine sites in northern Italy, Atmos. Environ., 34, 1455-1470, 2000.

Bardouki, H., Liakakou, H., Economou, C., Sciare, J., Smolik, J., Zdimal, V., Eleftheriadis, K., Lazaridis, M., Dye, C., and Mihalopoulos, N.: Chemical composition of size-resolved atmospheric aerosols in the eastern mediterranean during summer and winter, Atmos. Environ., 37, 195-208, 2003.

Bergametti, G.: Apports atmosphériques à la Mediterranée occidentale: aspects géochimiques et météorologiques, Thèse de Doctorat ès Sciences, Univ. Paris 7, 302 pp., 1987.

Bergametti, G., Dutot, A. L., Buat-menard, P., Losno, R., and Remoudaki, E.: Seasonal variability of the elemental composition of atmospheric aerosol particles over the northwestern Mediterranean, Tellus B, 41, 353-361, 1989.

Biegala, I. C. and Raimbault, P.: High abundance of diazotrophic picocyanobacteria $(<3 \mu \mathrm{m})$ in a Southwest Pacific coral lagoon, Aquat. Microb. Ecol., 51, 45-53, 2008.

Blain, S., Bonnet, S., and Guieu, C.: Dissolved iron distribution in the tropical and sub tropical South Eastern Pacific, Biogeosciences, 5, 269-280, doi:10.5194/bg-5-269-2008, 2008.

Blain, S., Quéguiner, B., Armand, L., Belviso, S., Bombled, B., Bopp, L., Bowie, A., Brunet, C., Brussaard, K., Carlotti, F., Christaki, U., Corbière, A., Durand, I., Ebersbach, F., Fuda, J. L., Garcia, N., Gerringa, L. J. A., Griffiths, F. B., Guigue, C., Guillerm, C., Jacquet, S., Jeandel, C., Laan, P., Lefèvre, D., Lomonaco, C., Malits, A., Mosseri, J., Obernosterer, I., Park, Y. H., Picheral, M., Pondaven, P., Remenyi, T., Sandroni, V., Sarthou, G., Savoye, N., Scouarnec, L., Souhault, M., Thuillers, D., Timmermans, K. R., Trull, T., Uitz, J., Van-Beek, P., Veldhuis, M. J. W., Vincent, D., Viollier, E., Vong, L., and Wagener, T.: Effect of natural iron fertilisation on carbon sequestration in the Southern Ocean, Nature, 446, 1070-1074, 2007. 
Bonnet, S. and Guieu, C.: Atmospheric forcing on the annual iron cycle in the western Mediterranean Sea: A 1-year survey, J. Geophys. Res., 111(C9), C09010, doi:10.1029/2005JC003213, 2006.

Boyd, P. W., Jickells, T., Law, C. S., Blain, S., Boyle, E. A., Buesseler, K. O., Coale, K. H., Cullen, J. J., de Baar, H. J. W., Follows, M., Harvey, M., Lancelot, C., Levasseur, M., Owens, N. P. J., Pollard, R., Rivkin, R. B., Sarmiento, J., Schoemann, V., Smetacek, V., Takeda, S., Tsuda, A., Turner, S., and Watson, A. J.: Mesoscale iron enrichment experiments 1993-2005: Synthesis and future directions, Science, 315(5812), 612-617, 2007.

Chatenet, B., Marticorena, M., Gomes, L., and Bergametti, G.: Assessing the microped size distributions of desert soils erodible by wind, Sedimentology, 43, 901-911, 1996.

Claquin, T., Schulz, M., and Balkanski, Y. J.: Modeling the mineralogy of atmospheric dust sources, J. Geophys. Res., 104 (D18), 22243-22256, 1999.

Cwiertny, D. M., Hunter, G. J., Pettibone, J. M., Scherer, M. M., and Grassian, V. H.: Surface chemistry and dissolution of $\alpha$ FeOOH nanorods and microrods: Environmental implications of size-dependent interactions with oxalate, J. Phys. Chem. C, 113, 2175-2186, doi:10.1021/jp807336t, 2009.

de Baar, H. J. W., Boyd, P. W., Coale, K. H., Landry, M. R., Tsuda, A., Assmy, P., Bakker, D. C. E., Bozec, Y., Barber, R. T., Brzezinski, M. A., Buesseler, K. O., Boye, M., Croot, P. L., Gervais, F., Gorbunov, M. Y., Harrison, P. J., Hiscock, W. T., Laan, P., Lancelot, C., Law, C. S., Levasseur, M., Marchetti, A., Millero, F. J., Nishioka, J., Nojiri, Y., van Oijen, T., Riebesell, U., Rijkenberg, M. J. A., Saito, H., Takeda, S., Timmermans, K. R., Veldhuis, M. J. W., Waite, A. M., and Wong, C. S.: Synthesis of iron fertilization experiments: From the iron age in the age of enlightenment, J. Geophys. Res., 110, C09S16, doi:10.1029/2004JC002601, 2005.

De Falco, G., Molinaroli, E., and Rabitti, S.: Grain size analysis of aerosol and rain particles: a methodological comparison, in The Impact of Desert Dust Across the Mediterranean, edited by: Guerzoni, S. and Chester, R., Kluwer, 233-238, 1996.

Derimian, Y., Karnieli, A., Kaufman, Y. J., Andreae, M. O., Andreae, T. W., Dubovik, O., Maenhaut, W., Koren, I., and Holben, B. N.: Dust and pollution aerosols over the Negev desert, Israel: Properties, transport, and radiative effect, J. Geophys. Res., 111, D05205, doi:10.1029/2005JD006549, 2006.

Desboeufs, K. V. and Cautenet, G.: Transport and mixing zone of desert dust and sulphate over Tropical Africa and the Atlantic Ocean region, Atmos. Chem. Phys. Discuss., 5, 56155644, doi:10.5194/acpd-5-5615-2005, 2005.

Desboeufs, K. V., Losno, R., and Colin, J.-L.: Factors influencing aerosol solubility during cloud process, Atmos. Environ., 35, 3529-3537, 2001.

Desboeufs, K., Guieu C. and Leblond, N.: Chemical and mass budget in sediment traps after dust fertilisation in large mesocosm: Assessment of new dust tracer to estimate lithogenic fluxes, in preparation, 2010.

Dulac, F.: Dynamique du transport et des retombées d'aérosols métalliques en Méditerranée occidentale, Thèse de Sciences, University of Paris 7, 241 pp., 1986.

Dulac, F., Buat-Ménard, P., Ezat, U., Melki, S., and Bergametti, G.: Atmospheric input of trace metals to the western Mediterranean: uncertainties in modelling dry deposition from cascade impactor data, Tellus B, 41, 362-378, 1989.

Dulac, F., Bergametti, G., Losno, R., Remoudaki, E., Ezat, U., and Buat-Ménard, P.: Dry deposition of mineral aerosol particles in the marine atmosphere: Significance of the large size fraction, in: Precipitation Scavenging and Atmosphere-Surface Exchange, edited by: Schwartz, S. E. and Slinn, W. G. N., Hemisphere, Richland, Wa., 2, 841-854, 1992.

Dulac, F., Moulin, C., Planquette, H., Schulz, M., and Tartar, M.: African dust deposition and ocean colour in the eastern Mediterranean, in Proc. 37th CIESM Congress, Barcelona, 711 June 2004, Rapp. Comm. Int. Mer Médit., Monaco, 37, 190, 2004.

Dulac, F., Desboeufs, K., Laurent, B., Bon Nguyen, E., Schmechtig, C., Bergametti, G., Losno, R., Marticorena, B., Guieu, C., and Loÿe-Pilot, M. D.: Aeolian dust deposition in the western Mediterranean and the project ChArMEx, in Proc. 39th CIESM Congress, Venezia, 10-14 May 2010, Rapp. Comm. Int. Mer Médit., 39, 242, 2010

Emerson, S., Quay, P., Karl, D., Winn, C., Tupas, L., and Landry, M.: Experimental determination of the organic carbon flux from open-ocean surface waters, Nature, 389, 951-954, 1997.

Falkovich, A. H., Ganor, E., Levin, Z., Formenti, P., and Rudich, Y.: Chemical and mineralogical analysis of individual mineral dust particles, J. Geophys. Res., 106, 18029-18036, 2001.

Formenti, P., Andreae, M. O., Andreae, T. W., Ichoku, C., Schebeske, G., Kettle, J., Maenhaut, W., Kafmeyer, J., Ptasinsky, J., Karnieli, A., and Lelieveld, J.: Physical and chemical characteristics of aerosols over the Negev Desert (Israel) during summer 1996, J. Geophys. Res., 106, 4871-4890, 2001.

Formenti, P., Rajot, J. L., Desboeufs, K., Caquineau, S., Chevaillier, S., Nava, S., Gaudichet, A., Journet, E., Triquet, S., Alfaro, S., Chiari, M., Haywood, J., Coe, H., and Highwood, E.: Regional variability of the composition of mineral dust from western africa: Results from the AMMA SOP0/DABEX and DODO field campaigns, J. Geophys. Res.-Atmos., 113, D00C13, doi:10.1029/2008JD009903, 2008.

Gibson, E. R., Hudson, P. K., and Grassian, V. H.: Aerosol chemistry and climate: Laboratory studies of the carbonate component of mineral dust and its reaction products, Geophys. Res. Lett., 33, L13811, doi:10.1029/2006GL026386, 2006.

Gomes, L., Bergametti, G., Coudé-Gaussen, G., and Rognon, P.: Submicron desert dusts: a sand blasting process?, J. Geophys. Res., 95(D9), 13927-13935, 1990.

Guerzoni, S., Landuzzi, W., Lenaz, R., Quarantotto, G., Rampazo, G., Molinaroli, E., Turetta, C., Visin, F., Cesari, G., and Cristini, S.: Fluxes of soluble and insoluble metals and nutrients from the atmosphere to the central Mediterranean Sea, in EROS 2000, European River Ocean System, Fourth Workshop on the NWMediterranean Sea, edited by: Martin, J.-M. and Barth, H., Water Poll. Res. Rep., 30, Commission of the European Communities, 253-260, 1993.

Guerzoni, S., Chester, R., Dulac, F., Herut, B., Loye-Pilot, M. D., Measures, C., Migon, C., Molinaroli, E., Moulin, C., Rossini, P., Saydam, C., Soudine, A., and Ziveri, P.: The role of atmospheric deposition in the biogeochemistry of the Mediterranean Sea, Prog. Oceanogr., 44, 147-190, 1999.

Guieu, C., Loÿe-Pilot, M.-D., Ridame, C., and Thomas, C.: Chemical characterization of the Saharan dust end-member; some biological implications for the western Mediterranean, J. Geophys. 
Res., 107, D15, doi:10.1029/2001JD000582, 2002.

Guieu, C. , Loÿe-Pilot, M.-D., Benyaya, L., and Dufour, A.: Spatial variability of atmospheric fluxes of metals $(\mathrm{Al}, \mathrm{Fe}, \mathrm{Cd}, \mathrm{Zn}$ and $\mathrm{Pb}$ ) and phosphorus over the whole Mediterranean from a oneyear monitoring experiment: biogeochemical implications, Mar. Chem., 120, 164-178, 2010.

Herut, B., Zohary, T., Krom, M. D., Mantoura, R. F. C., Pitta, P., Psarra, S., Rassoulzadegan, F., Tanaka, T., and Thingstad, T. F: Response of East Mediterranean surface water to Saharan dust: On-board microcosm experiment and field observations, DeepSea Res. Pt. II, doi:10.1016/j.dsr2.2005.09.003, 2005.

Hwang, H. and Ro, C.-U.: Direct observation of nitrate and sulfate formations from mineral dust and sea-salts using low-z particle electron probe x-ray microanalysis, Atmos. Environ., 40, 38693880, 2006.

Jickells, T. D., An, Z. S., Andersen, K. K., Baker, A. R., Bergametti, G., Brooks, N., Cao, J. J., Boyd, P. W., Duce, R. A., Hunter, K. A., Kawahata, H., Kubilay, N., LaRoche, J., Liss, P. S., Mahowald, N., Prospero, J. M., Ridgwell, A. J., Tegen, I., and Torres, R.: Global iron connections between desert dust, ocean biogeochemistry, and climate, Science, 308, 67-71, 2005.

Kalderon-Asael, B., Erel, Y., Sandler, A., and Dayan, U.: Mineralogical and chemical characterization of suspended atmospheric particles over the east Mediterranean based on synoptic-scale circulation pattern, Atmos. Environ., 43, 3963-3970, 2009.

Kandler, K., Benker, N., Bundke, U., Cuevas, E., Ebert, M., Knippertz, P., Rodríguez, S., Schütz, L., and Weinbruch, S.: Chemical composition and complex refractive index of saharan mineral dust at Izaña, Tenerife (Spain) derived by electron microscopy, Atmos. Environ., 41, 8058-8074, 2007.

Koçak, M., Mihalopoulos, N., and Kubilay, N.: Chemical composition of the fine and coarse fraction of aerosols in the northeastern Mediterranean, Atmos. Environ., 41, 7351-7368, 2007.

Krueger, B. J., Grassian, V. H., Cowin, J. P., and Laskin, A.: Heterogeneous chemistry of individual mineral dust particles from different dust source regions: The importance of particle mineralogy, Atmos. Environ., 38, 6253-6261, 2004.

Kubilay, N., Cokacar, T., and Oguz, T.: Optical properties of mineral dust outbreaks over the northeastern Mediterranean, J. Geophys. Res., 108, 4666, doi:10:1029/2003JD003798, 2003.

Labasque, T., Chaumery, C., Aminot, A., and Kergoat, G.: Spectrophotometric Winkler determination of dissolved oxygen: reexamination of critical factors and reliability, Mar. Chem., 88, 53-60, 2004.

Laghdass, M., Blain, S., Besseling, M., Catala, P., Guieu, C., and Obernosterer, I.: Impact of Saharan dust on the microbial community during a large clean mesocosm experiment in the NW Mediterranean Sea, Aquat. Microb. Ecol., accepted, 2010.

Levin, Z., Teller, A., Ganor, E., and Yin, Y.: On the interactions of mineral dust, sea-salt particles, and clouds: A measurement and modeling study from the Mediterranean Israeli Dust Experiment campaign, J. Geophys. Res., 110, D20202, doi:10.1029/2005JD005810, 2005.

Longhurst, A., Sathyendranath, S., Platt, T., and Caverhill, C.: an estimate of global primary production in the ocean from satellite radiometer data, J. Plankton Res., 17(6), 1245-1271, 1995.

Losno, R., Bergametti, G., Carlier, P., and Mouvier, G.: Major ions in marine rainwater with attention to sources of alkaline and acidic species, Atmos. Environ., 25, 771-777, 1991.
Loÿe-Pilot, M. D. and Morelli, J.: Fluctuations of ionic composition of precipitations collected in Corsica related to changes in the origins of incoming aerosols, J. Aerosol Sci., 19, 577-585, 1988.

Loÿe-Pilot, M. D. and Martin, J.: The impact of desert dust across the Mediterranean, Kluwer, chapter Saharan dust input to the Western Mediterranean: An eleven years record in Corsica, 191199, 1996.

Löye-Pilot, M. D., Guieu, C., Klein, C., Mihalopoulos, N., Ridame, C., Dufour, A., Kouvarakis, G., Markakis, Z., and Oikonomou, C.: Les apports atmosphériques en milieu Méditerranéen nord occidental et leur évolution : Etude dans la réserve de biosphère du Fango, Travaux Scientifiques du Parc Régional de Corse et Réserve Naturelle, 65, 29-40, 2005.

Masmoudi, M., Chaabane, M., Tanré, D., Gouloub, P., Blarel, L., and Elleuch, F.: Spatial and temporal variability of aerosol: size distribution and optical properties, Atmos. Res., 66, 1-19, 2003.

Maring, H., Savoie, D. L., Izaguirre, M. A., Custals, L., and Reid, J. S.: Mineral dust aerosol size distribution change during atmospheric transport, J. Geophys. Res., 108(D19), 8592, doi:10.1029/2002JD002536, 2003.

Marticorena, B. and Bergametti, G.: Modeling of the atmospheric dust cycle: 1. Design of a soil derived dust emission scheme, J. Geophys. Res., 100, 16415-16429, 1995.

Marticorena, B., Bergametti, G., Aumont, B., Callot, Y., N'Doumé, C., and Legrand, M.: Modeling the Saharan dust cycle: 2. Simulation of Saharan dust sources, J. Geophys. Res., 102, 43874404, 1997.

Martin, J. H., Coale, K. H., Johnson, K. S., et al.: Testing the iron hypothesis in ecosystems of the equatorial Pacific Ocean, Nature, 371, 123-129, 1994.

Meskhidze, N., Chameides, W. L., Nenes, A., and Chen, G.: Iron mobilization in mineral dust: Can anthropogenic $\mathrm{SO}_{2}$ emissions affect ocean productivity?, Geophys. Res. Lett., 30(21), 2085, doi:10.1029/2003GL018035, 2003.

Mills, M. M., Ridame, C., Davey, M., La Roche, J., and Geider, R. J.: Iron and phosphorus co-limit nitrogen fixation in the eastern tropical North Atlantic, Nature, 429, 292-294, 2004.

Montoya, J. P., Voss, M., Kahler, P., and Capone, D. G.: A simple, high-precision, high-sensitivity tracer assay for N-2 fixation, Appl. Environ. Microbiol., 62(3), 986-993, 1996.

Moulin, C., Lambert, C. E., Dayan, U., Masson, V., Ramonet, M., Bousquet, P., Legrand, M., Balkanski, Y. J., Guelle, W., Marticorena, B., Bergametti, G., and Dulac, F.: Satellite climatology of African dust transport in the Mediterranean atmosphere, J. Geophys. Res., 103(D11), 13137-13144, doi:10.1029/98jd00171, 1998.

Murphy, J. and Riley, I.: A modified single solution method for the determination of phosphate in natural waters, Anal. Chim. Acta, 27, 31-36, 1962.

Muselli, M., Beysens, D., Marcillat, J., Milimouk, I., Nilsson, T., and Louche, A.: Dew water collector for potable water in Ajaccio (Corsica island, France), Atmos. Res., 64, 297-312, 2002.

Obernosterer, I., Catala, P., Reinthaler, T., Herndl, G. J., and Lebaron, P.: Enhanced heterotrophic activity in the surface microlayer of the Mediterranean Sea, Aquat. Microb. Ecol., 39(3), 293-302, 2005.

Olli, K. and Seppälä, J.: Vertical niche separation of phytoplankton: large-scale mesocosm experiments, Mar. Ecol.-Prog. Ser., 217, 219-233, 2001. 
Paris, R., Desboeufs, K., and Journet, E.: Variability of dust iron solubility in atmospheric waters: investigation on the role of organic complexation, Mar. Chem., in revision, 2010.

Peña, R. M., Garcia, S., Herrero, C., Losada, M., Vazquez, A., and Lucas, T.: Organic acids and aldehydes in rainwater in a northwest region of Spain, Atmos. Environ., 36, 5277-5288, 2002.

Pitty, A. F.: Particle size of the Saharan dust which fell in Britain in July 1968, Nature, 220, 364-365, 1968.

Pollard, R., Sanders, R., Mike Lucas, M., and Statham, P.: The Crozet Natural Iron Bloom and Export Experiment (CROZEX), Deep-Sea Res. Pt. II, 54, 1905-1914, 2007.

Pretorius, W., Weis, D., Williams, G., Hanano, D., Kieffer, B., and Scoates, J. S.: Complete Trace Elemental Characterization of Granitoid (USGSG-2,GSP-2) Reference Materials by High Resolution Inductively Coupled Plasma-Mass Spectrometry, Geostandard. Geoanal. Res., 30(1), 39-54, 2006.

Pulido-Villena, E., Wagener, T., and Guieu, C.: Bacterial response to dust pulses in the western Mediterranean: Implications for carbon cycling in the oligotrophic ocean, Global Biogeochem. Cy., 22, GB1020, doi:10.1029/2007GB003091, 2008.

Pulido-Villena, E., Rérolle, V., and Guieu, C.: Transient fertilizing effect of dust in P-deficient LNLC surface ocean, Geophys. Res. Lett., 37, L01603, doi:10.1029/2009GL041415, 2010.

Putaud, J.-P., Van Dingenen, R., Dell'Acqua, A., Raes, F., Matta, E., Decesari, S., Facchini, M. C., and Fuzzi, S.: Size-segregated aerosol mass closure and chemical composition in Monte Cimone (I) during MINATROC, Atmos. Chem. Phys., 4, 889-902, doi:10.5194/acp-4-889-2004, 2004.

Quereda Sala, J., Olcina Cantos, J., and Monton Chiva, E.: Red dust rain within the Spanish Mediterranean area, Climatic Change, 32, 215-228, 1996.

Quisefit, J. P., de Chateaubourg, P., Garivait, S., and Steiner, E.: Aerosol sample analyses by wavelength dispersive X-ray Spectrometry: use of bulk samples to calibrate the instrument, X-Ray Spectrom., 23, 59-64, 1994.

Quisefit, J. P. and Randrianarivony, E.: Validation de la méthode d'étalonnage en couche mince par utilisation de géostandards déposés sur filtres pour l'analyse élémentaire par SFX, J. Phys. IV France 08 (PR5) Pr5-359-Pr5-367, 1998.

Reid, J. S., Jonsson, H. H., Maring, H. B., Smirnov, A., Savoie, D. L., Cliff, S. S., Reid, E. A., Livingston, J. M., Meier, M. M., Dubovik, O., and Tsay, S.-C. : Comparison of size and morphological measurements of coarse mode dust particles from Africa, J. Geophys. Res., 108, 8593, doi:10.1029/2002JD002485, 2003.

Ridame, C. and Guieu, C.: Saharan input of phosphate to the oligotrophic water of the open western Mediterranean Sea, Limnol. Oceanogr., 47, 856-869, 2002.
Ridame, C., Ternon, E., Guieu, C., and L'Helguen, S.: Impact of a Saharan dust input on primary production and $\mathrm{N}_{2}$ fixation in Mediterranean Sea, International SOLAS Conference, 1519 November 2009, poster, Barcelona, 2009.

Ridame, C., Biegala, I., Dekaemacker, J., Bonnet, S., L'Helguen, S., and Guieu, C.,: Impact of a Saharan dust event on $\mathrm{N}_{2}$ fixation and diazotrophs abundance in the NW Mediterranean Sea: results from a large clean mesocosm experiment, in preparation, 2010.

Romano, J.-C., Bernard Di Martino, B., and Dominici, J.-M.: Etude des courants et de la turbidité des eaux à la limite inférieure de l'herbier de Posidonia Oceanica dans la réserve marine de Scandola, Rapport du Parc Régional de Corse, 10 pp., 2006.

Schulz, K. G., Riebesell, U., Bellerby, R. G. J., Biswas, H., Meyerhöfer, M., Müller, M. N., Egge, J. K., Nejstgaard, J. C., Neill, C., Wohlers, J., and Zöllner, E.: Build-up and decline of organic matter during PeECE III, Biogeosciences, 5, 707-718, doi:10.5194/bg-5-707-2008, 2008.

Smolík, J., Ždímal, V., Schwarz, J., Lazaridis, M., Havárnek, V., Eleftheriadis, K., Mihalopoulos, N., Bryant, C., and Colbeck, I.: Size resolved mass concentration and elemental composition of atmospheric aerosols over the Eastern Mediterranean area, Atmos. Chem. Phys., 3, 2207-2216, doi:10.5194/acp-3-2207-2003, 2003.

Solmon, F., Chuang, P. Y., Meskhidze, N., and Chen, Y.: Acidic processing of mineral dust iron by anthropogenic compounds over the north Pacific Ocean, J. Geophys. Res., 114, D02305, doi:10.1029/2008JD010417, 2009.

Tafuro, A. M., Barnaba, F., De Tomasi, F., Perrone, M. R., and Gobbi, G. P.: Saharan dust particle properties over the central mediterranean, Atmos. Res., 81, 67-93, 2006.

Ternon, E., Guieu, C., Loÿe-Pilot, M.-D., Leblond, N., Bosc, E., Gasser, B., Miquel, J.-C., and Martín, J.: The impact of Saharan dust on the particulate export in the water column of the North Western Mediterranean Sea, Biogeosciences, 7, 809-826, doi:10.5194/bg-7-809-2010, 2010.

Wagener, T., Guieu, C., and Leblond, N.: Effects of dust deposition on iron cycle in the surface Mediterranean Sea: results from a mesocosm seeding experiment, Biogeosciences Discuss., 7, 2799-2830, doi:10.5194/bgd-7-2799-2010, 2010.

Weiner, B. B., Tscharnuter, W. W., and Karasikov, N.: Improvements in accuracy and speed using the time-of-transition method and dynamic image analysis for particle sizing. Some real-world examples, in: Particle Size Distribution III: Assessment and Characterization, edited by: Provder, T., ACS Symp. Series, 693, Am. Chem. Soc., 88-102, 1998.

Zhang, J. I. A. and Chi, J. I. E.: Automated Analysis of Nanomolar Concentrations of Phosphate in Natural Waters with Liquid Waveguide, Environ. Sci. Technol., 38, 1048-1053, 2002. 